\title{
FORMULATION AND NUTRITIONAL EVALUATION OF HIGH PROTEIN DIET PRODUCED FROM YELLOW MAIZE (Zea mays) SOYA BEAN (GLYCINE MAX), PUMPKIN (Cucurbita pepo) SEED AND FISH (Alestes nurse) MEAL
}

\author{
${ }^{* 1}$ Chamba, G., ${ }^{1}$ Falmata, A. S., ${ }^{1}$ Bintu B. P., ${ }^{2}$ Maryam, B. K. \& ${ }^{1}$ Modu, S. \\ ${ }^{*}$ Department of Biochemistry, Faculty of Science. University of Maiduguri Nigeria. \\ ${ }^{2}$ Department of Biological Science, Faculty of Science, University of Maiduguri, Nigeria. \\ *Corresponding Author Email: gonichamba97@gmail.com
}

\section{ABSTRACT}

The aim of this study was to produce high protein diet for growing children from yellow maize, soya bean, pumpkin seed and fish meal. The raw materials were subjected to different processing techniques. The yellow maize (YM) was blended with different proportions of soya bean (SB), pumpkin seeds (PS) and fish meal (FM) with a view to formulating a high protein diet to address protein Energy Malnutrition. The formulated food Blends were; Blend 1 (70 \% YM: $30 \%$ SB), Blend 2 (70 \% YM: $30 \%$ PS), Blend 3 (70 \% YM: $30 \%$ FM), Blend 4 (70 \% YM: $20 \%$ SB :10 \% PS), Blend 5 (70 \% YM: $15 \%$ SB: $15 \%$ FM), Blend 6 (60 \% YM: $20 \%$ PS: $20 \%$ FM), and a therapeutic milk (F-100) was used as a control diet. The raw materials and the food Blends were assayed for proximate, mineral, vitamin content and amino acid profile. The data obtained were analyzed statistically. The results of the proximate composition showed significant $(\mathrm{p}<0.05)$ decrease in moisture, protein, total fat and fibre contents of the fermented yellow maize, roasted soya bean and pumpkin seed while that of the dried fish showed significant $(\mathrm{P}<0.05)$ increase. The results shows that food Blend 6 had highest values for protein $(17.77 \pm 0.09 \%)$, total fat $(6.00 \pm 0.27 \%)$ and total energy $(388.10 \pm 0.29 \mathrm{Kcal} / 100 \mathrm{~g})$. A Significant $(\mathrm{P}<0.05)$ difference was observed in the mineral element content of yellow maize and fish meal after fermentation and drying respectively, while an increase was observed in roasted soya bean and pumpkin seed. The food Blend 5 recorded higher value for $\mathrm{Na}$, and $\mathrm{K}$, while the control diet had higher value for $\mathrm{P}, \mathrm{Zn}, \mathrm{Fe}$ and $\mathrm{Cu}$. An increase in B-group vitamins, and vitamin $\mathrm{C}$, were observed in the samples, while decreased in fat soluble vitamins $\mathrm{A}$ and $\mathrm{E}$ were observed in fermented yellow maize and dried fish, while decrease was observed in roasted soybean and pumpkin seed. The control diet had higher value for all the vitamins analyzed compared to the food Blends, except for vitamin A and E. The result of the amino acid profile showed that the levels of the essential amino acids were increased in the fermented yellow maize, and dried fish, while a reduction was observed in roasted soya bean and pumpkin seed. However, all the prepared food Blends were enhanced in terms of essential amino acid, but more enhanced in food Blend 6, followed very closely by food Blend 5. The amino acid profile of the control Blend was higher than those of the food Blends1, 2,3 and 4. Thus, the high energy and protein contents of the formulated diets are adequate in the management of PEM.

Keywords: therapeutic, high protein diet, pumpkin seed and yellow maize

LICENSE: This work by Open Journals Nigeria is licensed and published under the Creative Commons Attribution License 4.0 International License, which permits unrestricted use, distribution, and reproduction in any medium, provided this article is duly cited. 


\section{INTRODUCTION}

Protein-energy malnutrition (PEM) is an early childhood disease which causes a high rate of morbidity and mortality of children less than 5 years old. It represents the main child health problem in the developing countries. Inadequate dietary and diseases are the immediate causes or determinant of malnutrition (WHO/UNICEF, 2018). Kwashiorkor is a form of protein-energy malnutrition which occurs as a result of inadequate intake of dietary protein. Factors that lead to kwashiorkor include lack of nutritional knowledge, socio-economic status, inappropriate infant feedings and weaning.

Weaning is a transition between the gradual withdrawals from mother's breast milk to family diet. Malnutrition, especially kwashiorkor, is most common in this transitional period (Shishira, 2016). The child is usually weaned into porridge prepared from mono cereal flour such as maize, millet, and sorghum which are characterized by bulky, high viscosity and low energy density per unit volume of the food. Apart from energy, the foods are usually inadequate in other nutrients such as essential amino acid like lysine, and mineral elements such as $\mathrm{P}, \mathrm{Mg}, \mathrm{Mn}$ and $\mathrm{Zn}$, leading to widespread protein-energy malnutrition during the weaning periods, and exacerbations are due to the high cost of therapeutic food such as ready to use therapeutic food (RUTF) and therapeutic milk (F-75 and F-100).

Nigeria is no exception as most children are weaned onto mono cereals (such as maize, wheat or millet) which are lacking in essential amino acid (e.g., lysine) (Elemo et al., 2011). Nutritional status assessment methods used in detecting and monitoring recovery of patients suffering from PEM include; clinical methods, morphological methods, haematological and biochemical methods, dietary survey and anthropometry. Serum albumin and total serum proteins are markedly decreased during protein-energy malnutrition (Shishira, 2016).

A major factor among the dietary causes of protein-energy malnutrition (PEM) is deficiency in energy intake (WHO/UNICEF, 2018). Kwashiorkor, fatty liver and/or atrophy of the liver resulting in increased level of aspartate amino transferase enzyme in the blood, occurs in PEM subjects (Islam et al., 2007). Infections associated with PEM are largely due to decrease in efficiency of patients' immune system, hence the use of the WBC total (white blood cell) count as a diagnostic tool of PEM (Huang and Fraker, 2003). In dietary therapy for optimum recovery, dietary energy intake, treatment of infections, dietary protein intake and correction of electrolyte imbalance are imperative. Disappearance of apathy, oedema, anorexia, and gain in body weight and increase in nervous motor activity are signs of recovery from kwashiorkor (Etukudo et al., 1999).

The recommended daily allowance for dietary protein is based on the requirement that dietary protein be provided by a mixture of both animal and plant proteins. The addition of 20 to $30 \%$ of animal protein to a 7:3 combination of cereal to legume seed meal, increases ultimately the nutritive value of the food, and is consistent with the Protein Advisory Group (PAG) guidelines for weaning foods, which states that dietary protein content of weaning foods, should be at least $20 \%$ of animal protein (on a dry weight basis) (FAO/WHO, 2017). Variations in performance characteristics could occur, as a result of disease conditions such as protein-energy malnutrition (Obimba, 2006). Performance characteristics of dietary protein (Tome and Cecile, 2000), measured in net protein utilization (NPU) was used in determining the qualities of the diets. The unavailability of nutritious food, lack of nutritional knowledge, inappropriate infant feeding, socio-economic status, and high cost of commercially prepared food such as Friedso® cream and Cerelac $®$, therapeutic foods such Ready to Use Therapeutic Food (RUTF), and Formula 75 and 100 (F-75 
and F-100) in developing countries are the main causes of Protein-Energy Malnutrition (PEM) especially kwashiorkor in infants and children. Therefore, developing nutrient-dense, safe, affordable and accessible high -Protein diet from locally sourced ingredients has been strongly recommended as a viable and sustainable approach to address the problems of kwashiorkor. Thus, there is need to develop a cereal-based high protein diet from yellow maize (Zea mays), soya bean (Glycine max), pumpkin seeds (Cucurbita pepo) and fish (Alestes nurse) meal as an alternative for the management of kwashiorkor.

\section{MATERIALS AND METHODS}

\section{SAMPLE COLLECTION, PREPARATION AND PROCESSING}

\section{SAMPLE COLLECTION}

Yellow maize, soya beans and pumpkin seeds were obtained from Gamboru market, while fish was obtained from Alau Dam, in Maiduguri, Borno State, Nigeria, and authenticated by plant botanist for the plant samples and an ichthyologist for the fish samples, in the Departments of Biological Sciences and Fisheries, University of Maiduguri respectively.

\section{PREPARATION OF SAMPLES}

\section{PREPARATION OF YELLOW MAIZE}

Exactly $10 \mathrm{~kg}$ of yellow maize was sorted for stones, dirt, insects and defects. The grains without defect were cleaned. The yellow maize was dehulled at a local mill and winnowed to separate the hulls from the grains. The yellow maize was soaked in two litres (2L) of water for 72 hours for fermentation to take place. The fermented grains were transferred to a grease-free tray and sun-dried for 2 days. The grains were milled to fine powder and sieved pore of 5 $\mathrm{mm}$ to remove the larger bits so as to obtain smooth flour. The smooth flour obtained was stored in an airtight container until use (Oladeji, 2014).

\section{PREPARATION OF PUMPKIN SEED}

The pumpkin seeds were sorted for dirt, defects and insects, washed with water and sundried to a constant weight, roasted and ground into fine powder. The milled seeds were sieved through a 0.5 um mesh screen which gives the pumpkin seed flour.

\section{PREPARATION OF SOYA BEANS}

Defective grains (with holes), stones, dried pods and other debris were removed from the soya beans. The beans were washed and soaked in water for a day. This is done to remove some of the anti- nutritive agents such as trypsin inhibitors and haemaglutinins present in the beans. The soaked beans were then placed in a nylon sieve and allowed to drain. It was then lowered into a container containing already boiled water for about 20 minutes. This step is called "blanching". This is done to make dehulling easier, and to inactivate enzymes activity. The water was drained off and discarded. The dehulled beans were sundried after which it was roasted further to reduce anti- nutritive factors and improve upon the final product. The roasted soya beans were milled into flour to obtain smooth and consistent particle sizes (Elemo et al., 2010). 


\section{PREPARATION OF FISH MEAL}

The fish was obtained fresh and dried. The dried fish was cleaned and the flesh was separated from the bones, after which the fish was flaked into bits and oven dried. The flakes and bones were milled using a hand mill. The meal was sieved using $5 \mathrm{~mm}$ sieve for a powder (Bernard et al., 2018)

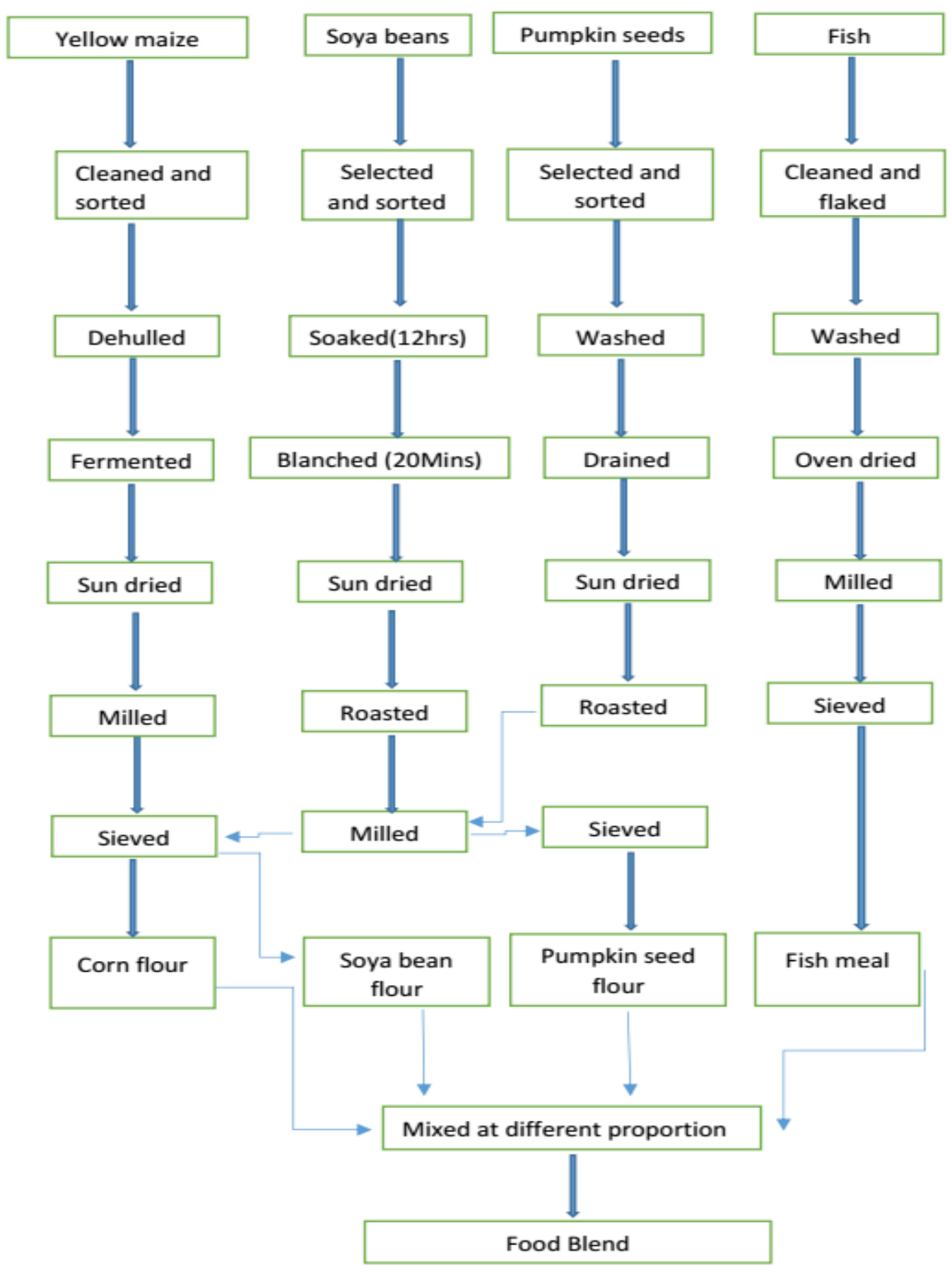

Figure1: Flow chart showing processing of different test materials (13) 


\section{FORMULATIONS OF VARIOUS FOOD BLENDS}

Formulations of yellow maize, soya beans, pumpkin seeds and fish meal were mixed together in varying ratios using Pearson's square method as shown in the Table 3.1

\section{METHODOLOGY}

\section{DETERMINATION OF PROXIMATE COMPOSITION}

Proximate analysis was carried out according to standard method described by AOAC (14) to determine the moisture content, ash content, crude protein, crude fibre, fat content, as well as carbohydrate composition of the blends. The respective methodology for each of the stated parameters is given below:

\section{DETERMINATION OF MOISTURE CONTENT (OVEN DRYING METHOD) PRINCIPLE}

This method is based on the loss of moisture on drying at an oven temperature of $105^{\circ} \mathrm{C}$. Besides water, the loss will include other matter volatile at $105^{\circ} \mathrm{C}$.

\section{PROCEDURE}

A clean flat dish made of silica was dried in an oven and cooled in desiccators. The cooled dish was then weighed $\left(\mathrm{W}_{1}\right)$. Sample (5 grams) was introduced and spread into the dish and weighed accurately $\left(\mathrm{W}_{2}\right)$. The dish and its content were transferred into an air oven at $105^{\circ} \mathrm{C}$ to dry for 3 hours. The dish was then transferred into desiccators and allowed to cool before weighing. The dish was returned to the oven for half an hour and again cooled in the desiccators and weighed. This process was repeated till a constant weight was attained $\left(\mathrm{W}_{3}\right)$.

Moisture Content $=\left(\mathrm{W}_{2}-\mathrm{W}_{3}\right) \times 100$

$$
\left(\overline{\left.\mathrm{W}_{2}-\mathrm{W}_{1}\right)}\right.
$$

Table 1: Percentage (\%) ratios of ingredients used if different food blends

\begin{tabular}{llllllll}
\hline Food samples & Blend 1 & Blend 2 & Blend 3 & Blend 4 & Blend 5 & Blend 6 & F- 100 \\
\hline Yellow maize & 70 & 70 & 70 & 70 & 70 & 60 & - \\
Soya bean & 30 & - & - & 20 & 15 & - & - \\
Pumpkin seed & - & 30 & - & 10 & - & 20 & - \\
Fish meal & - & - & 30 & - & 15 & 20 & - \\
\hline Total & $\mathbf{1 0 0}$ & $\mathbf{1 0 0}$ & $\mathbf{1 0 0}$ & $\mathbf{1 0 0}$ & $\mathbf{1 0 0}$ & $\mathbf{1 0 0}$ & $\mathbf{1 0 0}$
\end{tabular}

Key: Blend $1=70 \%$ yellow maize: $30 \%$ soya bean

Blend $2=70 \%$ yellow maize: $30 \%$ pumpkin seed

Blend $3=70 \%$ yellow maize: $30 \%$ fish meal

Blend $4=70 \%$ yellow maize: $20 \%$ soya bean: $10 \%$ pumpkin seed

Blend $5=70 \%$ yellow maize: $15 \%$ soya bean: $15 \%$ pumpkin seed

Blend $6=60 \%$ yellow maize: $20 \%$ soya bean: $20 \%$ fish meal

$\mathrm{F}-100=$ Commercial therapeutic milk (Formula 100) 


\section{DETERMINATION OF ASH CONTENT (GRAVIMETRIC METHOD) PRINCIPLE}

The organic component of food is burnt off in the oven. The residue is ash which consists of the inorganic components in the form of their oxides.

\section{PROCEDURE}

A silica dish was cleaned, ignited, cooled (in a desiccator and weighed $\left(\mathrm{W}_{1}\right)$. Test substance (5 grams) labeled $\mathrm{W}_{2}$ was weighed accurately directly into the silica dish. Using a pair of tongs, the weighed samples were placed in a muffle furnace and the temperature was set at $500^{\circ} \mathrm{C}$ until fully turned ash (grey colour of ash). Upon ashing, the dish with the ash was removed from the furnace and kept in a dessicator to cool before weighing $\left(\mathrm{W}_{3}\right)$.

$$
\% \text { Ash }=\frac{\left(\mathrm{W}_{3}-\underline{\left.\mathrm{W}_{1}\right) \times 100}\right.}{\left(\mathrm{W}_{2}-\mathrm{W}_{1}\right)}
$$

\section{DETERMINATION OF FIBRE CONTENTS}

Two grams ( $2 \mathrm{~g})$ of the sample was weighed and transferred into $250 \mathrm{ml}$ quick conical flask, $100 \mathrm{ml}$ of the digestion mixture was added and refluxed with occasional shaking for 45 minutes. The mixture was filtered through ashless filter paper using gentle suction. This was washed with $100 \mathrm{ml}$ of boiling water and $50 \mathrm{ml}$ of alcohol followed by 50 $\mathrm{ml}$ of petroleum ether. The filter paper with the sample was dried at $100^{\circ} \mathrm{C}$ to constant weight. The filter paper was weighed to obtain the weight of the residue. The residue was then put in a crucible which was already weighed and ashed at $600^{\circ} \mathrm{C}$ in a muffle furnace for 4 hours. The crucible was then removed and placed in a desiccator to cool after which it was weighed again. The percentage of crude fibre was calculated using the relation below;

$$
\% \text { of crude fibre }=\mathrm{C}-\mathrm{F} \mathrm{X} 100
$$

Where

$\mathrm{b}=$ weight of paper +residue

$\mathrm{a}=$ weight of paper alone

$\mathrm{C}=\mathrm{b}-\mathrm{a}=$ weight of residue

$\mathrm{e}=$ weight of dish + ash

$\mathrm{d}=$ weight of dish alone

$\mathrm{F}=\mathrm{e}-\mathrm{d}=$ weight of ash

$\mathrm{C}-\mathrm{F}$ = weight of crude fibre

DETERMINATION OF FAT CONTENT (SOXHLET EXTRACTION METHOD) PRINCIPLES Gravimetric estimation of fat from a dry powdered solid after a continuous extraction with light organic solvent (Petroleum ether, $\left.40-60^{\circ} \mathrm{C}\right)$.

\section{PROCEDURE}

Five grams $(5 \mathrm{~g})$ of the samples were accurately weighed (W) using a weighing dish. The flat-bottom flask was weighed $\left(\mathrm{W}_{1}\right)$ before the extractor was mounted on it. The thimble was held halfway into the extractor and the weighed 
sample was carefully transferred into the thimble. The weighing dish was rinsed with petroleum ether and poured into the thimble. The thimble was plugged with cotton wool and dropped fully into the extractor. The solvent was thereafter poured to reach about two thirds of the volumes of the flask and continuous extraction took place for five hours. When extraction is completed, the solvent was evaporated on water bath at $60^{\circ} \mathrm{C}$ followed by drying of the residue. The flask and residue were cooled and weighed $\left(\mathrm{W}_{2}\right)$.

$$
\frac{\left.\mathrm{W}_{2}-\mathrm{W}_{1}\right)}{\mathrm{W}} \times 100
$$

\section{DETERMINATION OF PROTEIN CONTENT (KJELDAHL METHOD) PRINCIPLE}

This method will not include nitrogen from nitrites and nitrates but will include nitrogen from protein, alkaloid, nucleic acids, etc. The organic matter is oxidized by concentrated sulphuric acid in the presence of catalyst and the Nitrogen converted to Ammonium sulphate.

Protein determination involves three major stages; they include:

- Digestion

- Distillation

- Titration

\section{DIGESTION OF SAMPLE}

Two grams ( $2 \mathrm{~g}$ ) of sample was weighed into a digesting tube (Kjedahl digestion tubes) and $20 \mathrm{ml}$ of sulphuric acid were added. The digester was connected and allowed to run for 3 hours. Fifty millilitres $(50 \mathrm{ml})$ of $40 \% \mathrm{NaOH}$ were added, and the volume was made up to $100 \mathrm{ml}$ using distilled water.

\section{DISTILLATION}

Five millilitres $(5 \mathrm{ml})$ of Borate $(2 \%)$ was introduced into a conical flask and 3 drops of bromocresol and methylene indicator was added into the conical flask. Five millilitres of digested sample were introduced into the distillation flask through the funnel and twenty (20 mls) of $40 \% \mathrm{NaOH}$ was also added into the distillation flask. All the inlets were closed. The conical flask containing the borate and mixed indicators was placed at the extended tube (outlet) of the distillate unit $75 \mathrm{ml}$ of the distillate was collected into the conical flask, and titrated against1M HCl.

\section{STANDARDIZATION OF HCI}

Five millilitres (5 ml) of ammonium solution was pipetted and distilled with about $15 \mathrm{ml}$ of $40 \% \mathrm{NaOH}$ solution. The liberated ammonia will be collected in a conical flask containing $5 \mathrm{ml}$ of $2 \%$ boric acid and 4 drops of mixed indicator. The ammonia solution was titrated with the standard $0.1 \mathrm{M} \mathrm{HCl}$. The amount of $\mathrm{HCl}$ required for the titration was the acid factor (A) that was used in the calculation of the crude protein content of the samples

The percentage protein was calculated using the formula:

$\%$ Crude Protein $=\quad \underline{A}$ X N X F X 14.007

Weight of sample $\mathrm{x}$ aliquot taken 
Where; $\quad \mathrm{A}=$ Volume of the acid used, $\mathrm{N}=$ Molarity of the acid and $\mathrm{F}=$ Factor 6.25

\section{DETERMINATION OF SOLUBLE CARBOHYDRATE CONTENT (BY DIFFERENCE)}

The carbohydrate contents were obtained by difference after the subtraction of total crude protein, fat, ash and crude fibre from the total dry matter.

$\%$ carbohydrate $=100-(\%$ Moisture $+\%$ protein $+\%$ fat $+\%$ ash $+\%$ crude fibre $)$

DETERMINATION OF TOTAL ENERGY CONTENT (FORMULA METHOD)

The total energy values were determined according to the formula used below;

Total Energy $(\mathrm{Kcal} / 100 \mathrm{~g} / 100 \mathrm{~g})=(\%$ available carbohydrate $\mathrm{x} 4)(\%$ protein $\mathrm{x} 4+(\%$ fat $\mathrm{x} 9)$

\section{DETERMINATION OF MINERAL ELEMENT}

Atomic absorption spectrophotometer (AAS) AA 6800 series shimazocorp was used for the determination of $\mathrm{Ca}, \mathrm{Na}$, $\mathrm{K}, \mathrm{Fe}, \mathrm{Mn}, \mathrm{Mg}, \mathrm{F}$ and $\mathrm{Zn}$. Two grams of samples were weighed into a crucible and incinerated at $600^{\circ} \mathrm{C}$ in a carbolite muffle furnace for three (3) hours. To the ash sample, exactly $10.0 \mathrm{ml}$ of $6 \mathrm{~N} \mathrm{HCl}$ was added and placed on a water bath and boiled for 10 minutes. The samples were removed and filtered into $100 \mathrm{ml}$ volumetric flask. The filter paper was washed down and the volume was made up to $100 \mathrm{ml}$ using deionized water. Ten millilitres of the digested sample were transferred to the sample container and aspirated to the AAS; reading was recorded in ppm (AOAC, 2012).

The appropriate lamps and correct wavelength for each element is specified in instruction manual as follows: $\mathrm{Fe}=248.3 \mathrm{~nm}, \mathrm{~K}=766.5 \mathrm{~nm}, \mathrm{Zn}=213.9 \mathrm{~nm}, \mathrm{Mn}=279.5 \mathrm{~nm}, \mathrm{Na}=589.0 \mathrm{~nm}, \mathrm{Ca}=422.7 \mathrm{~nm}, \mathrm{Mg}=285.23 \mathrm{~nm}$

\section{EXTRACTION OF SAMPLE FOR VITAMIN ANALYSIS}

Exactly $0.2 \mathrm{~g}$ of the samples was placed into $100 \mathrm{ml}$ volumetric flasks; $80 \mathrm{ml}$ of water was added to each flask. After 15 minutes of ultrasonic mixing, the samples were spinned at $5000 \mathrm{rpm}$ for 30 minutes. The supernatant was filtered through 0.45 um nylon membrane filter (Ekinci and Kadaka, 2005).

\section{PREPARATION OF VITAMIN WORKING STANDARDS}

A working solution of the standards of vitamins $B_{1}, B_{2}, B_{6}$ and vitamin $C$ of concentrations of $0.01 \mathrm{mg} / \mathrm{ml}, 0.02 \mathrm{mg} / \mathrm{ml}$, $0.03 \mathrm{mg} / \mathrm{ml}, 0.04 \mathrm{mg} / \mathrm{ml}$ and $0.05 \mathrm{mg} / \mathrm{ml}$ for all the vitamin groups were prepared by dissolving $25 \mathrm{mg}$ of the reference standard weighed accurately into $25 \mathrm{ml}$ of the mobile phase ( $0.1 \% \mathrm{TFA})$, and then diluted accordingly to obtain the above concentrations (USP, 2017). Five different concentrations of each of the standards were used to prepare the calibration curve plot. A calibration plot was prepared for each of the standards.

\section{DETERMINATION OF VITAMINS}

A Merck-Hitachi liquid chromatography system (Merck Darmstadi, Germany) equipped with a Model L-600 pump, a model AS-200 automatic injector and a model L-4000 variable wavelength UV/Vis detector was used. The chromatographic column is a reversed phase chromatographic column, particle size $5 \mu$ (Merck). The mobile phase was $0.1 \%$ TFA (Triflouroacetic acid) and $100 \% \mathrm{ACN}$ (Acetonitrile) with a flow rate of $1.8 \mathrm{ml} / \mathrm{min}$. The mobile phase was filtered through $0.45 \mu \mathrm{m}$ membrane and degassed using Ultrasonic machine before use. The UV/VIS detector was set at $260 \mathrm{~nm}$ 


\section{DETERMINATION OF AMINO ACID PROFILE}

The amino acid profile in the known sample was determined using methods described by (18). The known sample was dried to constant weight, defatted, hydrolyzed, and evaporated in a rotary evaporator and loaded into the Technicon sequential Multi-Sample Amino Analyzer (TSM).

\section{DEFATTING OF SAMPLE}

The samples were defatted using chloroform/methanol mixture of ratio 2:1. About $4 \mathrm{~g}$ of the samples were placed in extraction thimble and extracted for 15 hours in soxhlet extraction apparatus (AOAC, 2012).

\section{HYDROLYSIS OF THE SAMPLE}

A known weight $(4 \mathrm{~g})$ of the defatted samples were weighed into glass ampoule and $7 \mathrm{mls}$ of $6 \mathrm{~N} \mathrm{HCl}$ was added. Oxygen was expelled by passing nitrogen into the ampoule (this was to avoid possible oxidation of some amino acids during hydrolysis e.g., methionine and cystine). The glass ampoule was sealed with Bunsen burner flame and placed in an oven preset at $105^{\circ} \mathrm{C} \pm 5^{\circ} \mathrm{C}$ for 22 hours. The ampoule was allowed to cool before broken open at the tip and the content was filtered to remove the contents. The filtrate was evaporated to dryness in hot air oven. The residue was dissolved with $5 \mathrm{ml}$ of acetate buffer $(\mathrm{pH}$ 2.0) and stored in plastic specimen bottles, which was kept in the freezer.

\section{LOADING OF THE HYDROLYSATE INTO TSM ANALYZER}

The amount loaded was between 5 to 10 micro litres. This was dispended into the cartridge of the analyzer. The TSM analyzer is designed to separate and analyse free acidic, neutral and basic amino acids of the hydrolysate. The period of an analysis lasted for 76 minutes.

\section{METHOD OF CALCULATING AMINO ACID VALUES FROM THE CHROMATOGRAM PEAKS}

An integrator attached to the analyzer calculates the peak area proportional to the concentration of each of the amino acids. Alternatively, the net height of each peak produced by the chart recorder of TSM (each representing an amino acid) was measured. Approximately area of each peak was obtained by multiplying the height with the width at halfheight.

The nor leucine equivalent (NE) for each amino acid in the standard mixture was calculated using the formula;

$\mathrm{NE} \quad=\quad \frac{\text { Area of Norleucine Peak }}{\text { Area of each Acid }}$

Area of each Acid

A constant $\mathrm{S}$ was calculated for each amino acid in the standard mixture: where $\mathrm{S}_{\mathrm{std}}=\mathrm{NE}_{\mathrm{std} x}$ Molecular weight $\mathrm{x} \mu \mathrm{MAA}_{\mathrm{std}}$.

Finally, the amount of each amino acid present in the sample was calculated in $\mathrm{g} / 16 \mathrm{gN}$ on $\mathrm{g} / 100 \mathrm{~g}$ protein using the following formula:

Concentration $(\mathrm{g} / 100 \mathrm{~g}$ protein $)=\mathrm{NH} \times \mathrm{W} @ \mathrm{NH} / 2 \times \mathrm{S}_{\text {std }} \times \mathrm{C}$

Where $\mathrm{C}=\quad$ Dilution $\times 16 \div \mathrm{NH} \times \mathrm{W}$ (nleu)

Sample Wt (g) x N\% x 10 x Vol. loaded 


Where: $\quad \begin{array}{lll}\mathrm{NH} & = & \text { Net height of norleucine } \\ \mathrm{W} & = & \text { Width at half height } \\ \text { nleu } & = & \text { Norleucine }\end{array}$

\section{RESULTS}

\section{PROXIMATE COMPOSITION OF THE INGREDIENTS AND THE FOOD BLENDS}

Table 2 presents the proximate composition of unprocessed and processed samples of yellow maize, soya beans and pumpkin seeds. A significant $(\mathrm{P}<0.05)$ decrease in moisture contents were observed in the fermented yellow maize $(5.00 \pm 0.12 \%)$, roasted soya beans $(4.00 \pm 0.12 \%)$, roasted pumpkin seed $(3.23 \pm 0.01 \%)$ and dried fish $(6.63 \pm$ $0.02 \%)$. The protein contents of fermented yellow maize $(3.25 \pm 0.03 \%)$ showed a significant $(\mathrm{P}<0.05)$ reduction when compared with unprocessed yellow maize $(4.16 \pm 0.03 \%)$, while roasted soya bean $(14.72+0.02 \%)$ and roasted pumpkin seed $(12.14 \pm 0.08 \%)$ did not show significant $(\mathrm{P}>0.05)$ difference when compared to unprocessed soya bean $(14.92 \pm 0.02 \%)$ and pumpkin seed $(12.36 \pm 0.12 \%)$, while dried fish showed a significant $(\mathrm{P}<0.05)$ increase in the protein content $(59.43 \%)$ when compared with unprocessed fish $(49.23 \pm 0.03 \%)$. A significant $(\mathrm{P}<0.05)$ decrease was observed in the total ash content of fermented yellow maize (1.06 $\pm 0.08 \%)$, roasted soya bean $(1.21 \pm 0.02 \%)$, pumpkin seed $(2.21 \pm 0.02 \%)$, while an increase in the total ash content of the dried fish $(2.50 \pm 0.02 \%)$ was observed when compared with unprocessed samples of yellow maize $(1.53 \pm 0.02 \%)$, soya bean $(2.71 \pm 0.01 \%)$, pumpkin seed $(3.00 \pm 0.03 \%)$ and fish $(3.52 \pm 0.02 \%)$. A significant $(\mathrm{P}<0.05)$ decrease in the fat and fibre contents of the fermented yellow maize, roasted soya bean, pumpkin seeds and dried fish were observed when compared with the unprocessed samples. The results of the total carbohydrates and total energy showed a significant $(\mathrm{P}<0.05)$ increase in the processed samples when compared with the unprocessed samples. 
Table 2: Proximate composition of unprocessed and processed maize, soya bean, pumpkin seed and fish meal samples

\begin{tabular}{|c|c|c|c|c|c|c|c|c|}
\hline \multirow[t]{2}{*}{ Samples } & \multicolumn{2}{|c|}{ Maize } & \multicolumn{2}{|c|}{ Soya beans } & \multicolumn{2}{|c|}{ Pumpkin Seed } & \multicolumn{2}{|l|}{ Fish } \\
\hline & Unprocessed & Fermented & Unprocessed & Roasted & Unprocessed & Roasted & Fresh & Dried \\
\hline Moisture (\%) & $7.47 \pm 0.32^{\mathrm{a}}$ & $5.00 \pm 0.12^{b}$ & $5.50 \pm 0.12^{\mathrm{a}}$ & $4.00 \pm 0.12^{b}$ & $4.33 \pm 0.09^{\mathrm{a}}$ & $3.23 \pm 0.01^{\mathrm{b}}$ & $12.12 \pm 0.01^{\mathrm{a}}$ & $6 . .63 \pm 0,02^{b}$ \\
\hline Protein (\%) & $4.16 \pm 0.03^{\mathrm{a}}$ & $3.25 \pm 0.03^{b}$ & $14.92 \pm 0.02^{\mathrm{a}}$ & $14.72 \pm 0.02^{\mathrm{a}}$ & $12.36 \pm 0.12^{\mathrm{a}}$ & $12.14 \pm 0.08^{\mathrm{a}}$ & $49.23 \pm 0.32^{\mathrm{a}}$ & $59.43 .00 \pm 0.01^{\mathrm{b}}$ \\
\hline $\operatorname{Ash}(\%)$ & $1.53 \pm 0.02^{\mathrm{a}}$ & $1.06 \pm 0.08^{b}$ & $2.71 \pm 0.01^{\mathrm{a}}$ & $1.21 \pm 0.02^{\mathrm{b}}$ & $3.00 \pm 0.03^{\mathrm{b}}$ & $3.21 \pm 0.02^{\mathrm{a}}$ & $3.52 \pm 0.02^{\mathrm{a}}$ & $2.50 \pm 0.02^{b}$ \\
\hline Fat $(\%)$ & $1.97 \pm 0.04^{\mathrm{a}}$ & $1.72 \pm 0.02^{b}$ & $5.43 \pm 0.01^{\mathrm{a}}$ & $3.29 \pm 0.08^{b}$ & $6.87 \pm 0.01^{\mathrm{a}}$ & $5.11 \pm 0.06^{b}$ & $18.82 \pm 0.01^{\mathrm{a}}$ & $13.23 \pm 0.01^{\mathrm{b}}$ \\
\hline Fibre $(\%)$ & $5.32 \pm 0.03^{\mathrm{a}}$ & $2.49 \pm 0.01^{b}$ & $8.21 \pm 0.01^{\mathrm{a}}$ & $4.15 \pm 0.01^{\mathrm{b}}$ & $6.21 \pm 0.01^{\mathrm{a}}$ & $5.28 \pm 0.01^{\mathrm{b}}$ & - & - \\
\hline Carbohydrate (\%) & $78.68 \pm 0.09^{b}$ & $86.48 \pm 0.16^{\mathrm{a}}$ & $63.24 \pm 0.04^{\mathrm{b}}$ & $72.63 \pm 0.12^{b}$ & $66.23 \pm 0.13^{\mathrm{a}}$ & $72.30 \pm 0.16^{\mathrm{a}}$ & $16.31 \pm 0.03^{\mathrm{a}}$ & $23.64 \pm 0.04^{b}$ \\
\hline $\begin{array}{l}\text { Total Energy } \\
\text { (Kcal/100 g) }\end{array}$ & $333.11 \pm 0.77^{\mathrm{b}}$ & $376.41 \pm 0.02^{\mathrm{a}}$ & $361.17 \pm 0.61^{\mathrm{b}}$ & $379.07 \pm 0.25^{\mathrm{a}}$ & $372.18 \pm 0.45^{\mathrm{a}}$ & $382.61 \pm 1.87^{\mathrm{b}}$ & $431.54 \pm 0.13^{\mathrm{a}}$ & $405.63 \pm 0.12^{b}$ \\
\hline
\end{tabular}

Values are mean \pm SEM, $n=3$

Values with different superscript along the row under the same heading, are significantly different $(\mathrm{P}<0.05)$ 
Table 3 also presents the proximate composition of the food blends. Blend 2 has the lowest moisture contents, followed closely by blend 1 . The moisture content of the control blend was lower compared to the prepared food blends. The moisture contents of all the samples were within FAO/WHO limit of $<5 \%$. However, they all exhibit low moisture content. Food blend 6 had a higher protein content of (17.77 $\pm 0.09 \%)$ followed by blend $5(17.21 \pm 0.12 \%)$, blend 2 had the lowest protein contents of $14.45 \pm 0.11 \%$ ) followed by blend $1(15.63 \pm 0.01 \%)$. There was no significant ( $>>0.05)$ difference in the total ash contents of blend $2(2.37 \pm 0.08 \%)$ and blend $1(2.13 \pm 0.19 \%)$. Blend 4 had the

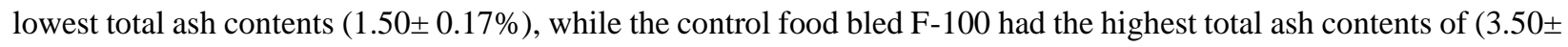
$0.29 \%)$. A highest fat content was recorded by a food blend $3(10.98 \pm 0.02 \%)$. There was significant $(\mathrm{P}<0.05)$ difference in the total fat contents of all the food blends including the control food blend (F-100), while blend 1(2.63 \pm 0.19 ) recorded the least total fat content. Data on the fibre contents showed that blend 2 had $5.59 \pm 0.22 \%$, which is also the highest, followed very closely by blend 4 with a value of $5.13 \pm 0.09 \%$. There was no significant ( $>0.05)$ difference in the fibre contents of blend $1(4.07 \pm 0.02 \%)$, blend $5(4.40 \pm 0.03 \%)$ and blend $6(4.46 \pm 0.27 \%)$. Blend 3 $(2.14 \pm 0.04 \%)$ has the lowest fibre content. Blend 1 had the highest carbohydrate content $(72.37 \pm 0.39 \%)$ followed closely by blend 2 , while blend 6 recorded the least content of carbohydrate. Total energy content study revealed that Food blend 6 had the highest value $(388.10 \pm 2.9 \mathrm{Kcal} / 100 \mathrm{~g})$, followed by food blend $5(386.14 \pm 0.31 \mathrm{Kcal} / 100 \mathrm{~g})$. The control food blend had a total energy content of $374.68 \pm 0.02$. Kcal/ $100 \mathrm{~g}$ 
Table 3: Proximate composition of food blends and control sample

\begin{tabular}{|c|c|c|c|c|c|c|c|c|}
\hline Samples & Blend 1 & Blend 2 & Blend 3 & Blend 4 & Blend 5 & Blend 6 & F-100 & FAO/WHO \\
\hline Moisture (\%) & $3.17 \pm 0.44^{\mathrm{a}}$ & $3.10 \pm 0.23^{\mathrm{a}}$ & $4.70 \pm 0.85^{\mathrm{a}}$ & $3.27 \pm 0.38^{\mathrm{a}}$ & $3.77 \pm 0.22^{\mathrm{a}}$ & $3.60 \pm 0.12^{\mathrm{a}}$ & $2.37 \pm 0.30^{b}$ & $<5$ \\
\hline Protein $(\%)$ & $15.63 \pm 0.20^{\mathrm{a}}$ & $14.45 \pm 0.11^{\mathrm{f}}$ & $16.83 \pm 0.02^{\mathrm{c}}$ & $16.08 \pm 0.05^{\mathrm{d}}$ & $17.21 \pm 0.12^{\mathrm{b}}$ & $17.77 \pm 0.09^{\mathrm{a}}$ & $16.92 \pm 0.02^{\mathrm{bc}}$ & $>15$ \\
\hline $\operatorname{Ash}(\%)$ & $2.13 \pm 0.19^{c}$ & $2.37 \pm 0.08^{c}$ & $3.51 \pm 0.23^{\mathrm{a}}$ & $1.50 \pm 0.17^{\mathrm{d}}$ & $2.47 \pm 0.15^{\mathrm{c}}$ & $2.99 \pm 0.15 \mathrm{~d}^{\mathrm{b}}$ & $3.50 \pm 0.29^{a}$ & $<3$ \\
\hline Fat $(\%)$ & $2.63 \pm 0.19^{f}$ & $4.83 \pm 0.02^{\mathrm{e}}$ & $10.98 \pm 0.02^{\mathrm{a}}$ & $5.44 \pm 0.06^{\mathrm{d}}$ & $5.90 \pm 0.04^{\mathrm{e}}$ & $6.00 \pm 0.27^{b c}$ & $2.16 \pm 0.03^{\mathrm{g}}$ & $10-25$ \\
\hline Fibre $(\%)$ & $4.07 \pm 0.20^{\mathrm{c}}$ & $5.59 \pm 0.22^{\mathrm{a}}$ & $2.14 \pm 0.04^{\mathrm{d}}$ & $5.13 \pm 0.09^{b}$ & $4.40 \pm 0.03^{c}$ & $4.46 \pm 0.27^{\mathrm{c}}$ & $2.16 \pm 0.03^{\mathrm{d}}$ & $<5$ \\
\hline Carbohydrate & $72.37 \pm 0.39^{a}$ & $69.66 \pm 0.26^{b}$ & $61.58 \pm 0.18^{f}$ & $68.58 \pm 0.07^{\mathrm{c}}$ & $66.25 \pm 0.02^{\mathrm{d}}$ & $64.72 . \pm 0.32^{\mathrm{e}}$ & $71.89 . \pm 0.15^{\mathrm{a}}$ & 64 \\
\hline $\begin{array}{l}\text { Total Energy } \\
\text { (Kcal) }\end{array}$ & $375.68 \pm 0.85^{\mathrm{d}}$ & $379.91 \pm 1.33^{\mathrm{cd}}$ & $412.41 \pm 0.02^{\mathrm{a}}$ & $387.76 \pm 0.02^{\mathrm{b}}$ & $38633 \pm 0.31^{\mathrm{b}}$ & $388.10 \pm 2.96^{\mathrm{d}}$ & $374.69 \pm 0.02^{c}$ & $400-425$ \\
\hline
\end{tabular}

Values are mean \pm SEM, $n=3$

Values with different superscript along the row are significantly different $(\mathrm{P}<0.05)$

Key: Blend $1=70 \%$ yellow maize: $30 \%$ soya bean

Blend $2=70 \%$ yellow maize: $30 \%$ pumpkin seed

Blend $3=70 \%$ yellow maize: $30 \%$ fish meal

Blend $4=70 \%$ yellow maize: $20 \%$ soya bean: $10 \%$ pumpkin seed

Blend 5=70\% yellow maize: 15 soya bean: $15 \%$ fish meal

Blend $6=60 \%$ yellow maize: $20 \%$ pumpkin seed: $20 \%$ fish meal

$\mathrm{F}-100=$ formula 100 control therapeutic diet 


\section{MINERAL ELEMENT COMPOSITION OF THE INGREDIENTS AND THE FOOD BLENDS}

The mineral element composition of the unprocessed and processed yellow maize, soya bean pumpkin seed and fish meal are presented in Table 4. There were significant $(\mathrm{P}<0.05)$ decrease in the levels of $\mathrm{Na}, \mathrm{K}, \mathrm{Mg}$ $\mathrm{P}$, and $\mathrm{Cu}$ in fermented yellow maize, when compared with the unprocessed yellow maize. A significant $(\mathrm{P}<0.05)$ decrease was observed in the Na content of roasted soya bean $(23.16 \pm 0.01 \mathrm{ug} / \mathrm{g})$ roasted pumpkin seed $(30.35 \pm 0.01 \mathrm{ug} / \mathrm{g})$ when compared to the unprocessed samples of soya bean and pumpkin seed with sodium content of $6.0 \pm 0.00 \mathrm{ug} / \mathrm{g}$ and $9.87 \pm 0.09 \mathrm{ug} / \mathrm{g}$ for unprocessed soy bean and pumpkin seed, respectively. A significant $(\mathrm{P}<0.05)$ decrease in $\mathrm{K}, \mathrm{Mg}, \mathrm{P}$ and $\mathrm{Cu} \mathrm{Ca}, \mathrm{Fe}$ and $\mathrm{Zn}$ contents was observed in roasted soya bean and pumpkin seed, when compared t the unprocessed samples of soya bean and pumpkin seed. A significant $(\mathrm{P}<0.05)$ increase in $\mathrm{Ca}, \mathrm{Zn}$ and $\mathrm{Fe}$ was observed in the fermented yellow maize when compared with the unprocessed yellow maize. There was significant $(\mathrm{P}<0.05)$ increase in the levels of all the mineral elements in the dried fish when compared to the unprocessed fish.

Table 5 present the mineral element levels for the food blends including the control blend. Food blend 4 had the highest $\mathrm{Na}$ content of $29.20 \pm 0.07 \mathrm{ug} / \mathrm{g}$ followed closely by food blend 2 with a Na content of $28.57 \pm 0.06 \mathrm{ug} / \mathrm{g}$. There was no significant $(\mathrm{P}>0.05)$ difference in the Na content of food blends $1(23.70 \pm$ $0.15 \mathrm{ug} / \mathrm{g})$, blend $3(24.27 \pm 0.01 \mathrm{ug} / \mathrm{g})$ and food blend $6(24.33 \pm 0.01 \mathrm{ug} / \mathrm{g})$. They all exhibited high Na level including the control blend (F-100). Blend 4 had higher value for $\mathrm{K}(4.73 \pm 0.44 \mathrm{ug} / \mathrm{g})$ followed closely by blend $6(4.437 \pm 0.44 \mathrm{ug} / \mathrm{g})$. Blend 1 recorded a least value for $\mathrm{K}(0.70 \pm 0.01 \mathrm{ug} / \mathrm{g})$. The control food blend $(\mathrm{F}-$ 100) had higher value for $\mathrm{Ca}(0.83 \pm 0.01 \mathrm{ug} / \mathrm{g})$. The blends 2 and 6 have very close values of $0.67 \pm 0.03 \mathrm{ug} / \mathrm{g}$ and $0.64 \pm 0.02 \mathrm{ug} / \mathrm{g}$ for calcium. 
Table 4: Mineral Element Content of Unprocessed and Processed Maize, Soya bean, Pumpkin seed and Fish Meal Samples

\begin{tabular}{|c|c|c|c|c|c|c|c|c|}
\hline \multirow[b]{2}{*}{ Minerals(ug/g) } & \multicolumn{2}{|c|}{ Maize } & \multicolumn{2}{|c|}{ Soya Beans } & \multicolumn{2}{|c|}{ Pumpkin Seed } & \multicolumn{2}{|l|}{ Fish } \\
\hline & Unprocessed & Fermented & Unprocessed & Roasted & Unprocessed & Roasted & Fresh & Dried \\
\hline $\mathbf{N a}$ & $18.70 \pm 0.15^{\mathrm{a}}$ & $10.87 \pm 0.32^{b}$ & $23.16 \pm 0.08^{b}$ & $19.15 \pm 0.02^{\mathrm{a}}$ & $29.35 \pm 0.04^{\mathrm{a}}$ & $27.67 \pm 0.01^{b}$ & $9.69 \pm 0.02^{b}$ & $11.54 \pm 0.01^{\mathrm{a}}$ \\
\hline $\mathbf{K}$ & $7.13 \pm 0.32^{\mathrm{a}}$ & $5.87 \pm 0.09^{\mathrm{b}}$ & $9.63 \pm 0.12^{\mathrm{a}}$ & $6.80 \pm 0.01^{b}$ & $10.27 \pm 0.09^{a}$ & $9.87 \pm 0.15^{b}$ & $3.15 \pm 0.02^{b}$ & $3.75 \pm 0.01^{\mathrm{a}}$ \\
\hline Mg & $0.72 \pm 0.01^{\mathrm{a}}$ & $0.61 \pm 0.00^{\mathrm{b}}$ & $0.35 \pm 0.01^{\mathrm{a}}$ & $0.23 \pm 0.01^{\mathrm{b}}$ & $0.57 \pm 0.01^{\mathrm{a}}$ & $0.42 \pm 0.01^{\mathrm{b}}$ & $0.02 \pm 0.012^{\mathrm{a}}$ & $0.03 \pm 0.01^{\mathrm{a}}$ \\
\hline $\mathbf{C a}$ & $0.20 \pm 0.01^{\mathrm{b}}$ & $0.29 \pm 0.01^{\mathrm{a}}$ & $0.72 \pm 0.02^{\mathrm{b}}$ & $0.75 \pm 0.01^{\mathrm{a}}$ & $0.76 \pm 0.01^{\mathrm{a}}$ & $0.71 \pm 0.01^{\mathrm{b}}$ & $0.29 \pm 0.03^{\mathrm{a}}$ & $1.28 \pm 0.01^{\mathrm{b}}$ \\
\hline $\mathbf{P}$ & $0.02 \pm 0.00^{\mathrm{a}}$ & $0.01 \pm 0.01^{\mathrm{a}}$ & $0.18 \pm 0.00^{\mathrm{a}}$ & $0.09 \pm 0.01^{b}$ & $0.30 \pm 0.01^{\mathrm{a}}$ & $0.27 \pm 0.01^{b}$ & $2.35 \pm 0.02^{b}$ & $2.42 \pm 0.01^{\mathrm{a}}$ \\
\hline Zn & $0.12 \pm 0.01^{\mathrm{b}}$ & $0.28 \pm 0.01^{\mathrm{a}}$ & $0.01 \pm 00.00^{\mathrm{a}}$ & $0.01 \pm 0.00^{\mathrm{a}}$ & $0.23 \pm 0.01^{\mathrm{a}}$ & $0.19 \pm 0.01^{\mathrm{b}}$ & $0.99 \pm 0.02^{\mathrm{b}}$ & $1.15 \pm 0.01^{\mathrm{a}}$ \\
\hline $\mathbf{F e}$ & $0.21 \pm 0.01^{\mathrm{b}}$ & $0.37 \pm 0.01^{\mathrm{a}}$ & $0.18 \pm 0.01^{\mathrm{a}}$ & $0.16 \pm 0.01^{\mathrm{a}}$ & $0.25 \pm 0.03^{\mathrm{a}}$ & $0.28 \pm 0.01^{\mathrm{b}}$ & $0.01 \pm 0.02^{\mathrm{a}}$ & $0.03 \pm 0.01^{\mathrm{b}}$ \\
\hline $\mathrm{Cu}$ & $0.18 \pm 0.01^{\mathrm{a}}$ & $0.12 \pm 0.12^{b}$ & $0.17 \pm 0.01^{\mathrm{b}}$ & $0.11 \pm 0.01^{b}$ & $0.22 \pm 0.01^{\mathrm{a}}$ & $0.19 \pm 0.01^{b}$ & ND & ND \\
\hline
\end{tabular}

Values are mean $\pm S E M, n=3$

Values with different superscripts along the row under the same heading, are significantly different $(\mathrm{P}<0.05)$

$\mathrm{ND}=$ Not detected

Table 5: Mineral Elements Composition of Food Blends

\begin{tabular}{|c|c|c|c|c|c|c|c|}
\hline $\begin{array}{l}\text { Minerals } \\
(\mathbf{u g} / \mathrm{g})\end{array}$ & Blend 1 & Blend 2 & Blend 3 & Blend 4 & Blend 5 & Blend 6 & F-100 \\
\hline $\mathbf{N a}$ & $23.70 \pm 0.15^{\mathrm{c}}$ & $28.50 \pm 0.06^{\mathrm{a}}$ & $24.27 \pm 0.09^{c}$ & $29.20 \pm 0.07^{a}$ & $25.77 \pm 0.15^{\mathrm{b}}$ & $24.33 \pm 0.09^{c}$ & $25.36 \pm 0.39^{b}$ \\
\hline $\mathbf{K}$ & $0.70 \pm 0.01^{\mathrm{e}}$ & $4.43 \pm 0.19^{b}$ & $1.70 \pm 0.06^{\mathrm{d}}$ & $4.73 \pm 0.03^{\mathrm{a}}$ & $1.93 \pm 0.15^{\mathrm{d}}$ & $4.47 \pm 0.44^{\mathrm{b}}$ & $3.30 \pm 0.06^{c}$ \\
\hline Mg & $0.16 \pm 0.01^{\mathrm{b}}$ & $0.30 \pm 0.06^{\mathrm{a}}$ & $0.13 \pm 0.01^{\mathrm{b}}$ & $0.14 \pm 0.01^{\mathrm{b}}$ & $0.08 \pm 0.01^{\mathrm{c}}$ & $0.23 \pm 0.01^{\mathrm{a}}$ & $0.27 \pm 0.01^{\mathrm{a}}$ \\
\hline $\mathbf{C a}$ & $0.45 \pm 0.01^{\mathrm{c}}$ & $0.67 \pm 0.03^{b}$ & $0.43 \pm 0.03^{\mathrm{c}}$ & $0.38 \pm 0.01^{\mathrm{c}}$ & $0.24 \pm 0.02^{\mathrm{d}}$ & $0.64 \pm 0.02^{b}$ & $0.83 \pm 0.01^{\mathrm{a}}$ \\
\hline $\mathbf{P}$ & $0.02 \pm 0.00^{\mathrm{ab}}$ & $0.01 \pm 0.01^{\mathrm{c}}$ & $0.02 \pm 0.00^{\mathrm{b}}$ & $0.02 \pm 0.00^{\mathrm{b}}$ & $0.02 \pm 0.00^{\mathrm{b}}$ & $0.01 \pm 0.00^{\mathrm{c}}$ & $0.03 \pm 0.00^{\mathrm{a}}$ \\
\hline Zn & $0.09 \pm 0.01^{\mathrm{b}}$ & $0.10 \pm 0.00^{\mathrm{a}}$ & $0.02 \pm 0.00^{\mathrm{e}}$ & $0.04 \pm 0.00^{\mathrm{c}}$ & $0.01 \pm 0.00^{\mathrm{a}}$ & $0.03 \pm 0.00^{\mathrm{de}}$ & $0.23 \pm 0.00^{\mathrm{a}}$ \\
\hline $\mathbf{F e}$ & $0.17 \pm 0.01^{\mathrm{d}}$ & $0.43 \pm 0.02^{\mathrm{a}}$ & $0.13 \pm 0.02^{\mathrm{e}}$ & $0.22 \pm 0.01^{\mathrm{c}}$ & $0.07 \pm 0.01^{\mathrm{f}}$ & $0.19 \pm 0.00^{\mathrm{d}}$ & $0.33 \pm 0.01^{\mathrm{b}}$ \\
\hline $\mathrm{Cu}$ & $1.73 \pm 0.03^{\mathrm{a}}$ & $1.23 \pm 0.09^{\mathrm{d}}$ & $0.53 \pm 0.09^{f}$ & $1.40 \pm 0.06^{\mathrm{cd}}$ & $1.33 \pm 0.02^{\mathrm{eb}}$ & $1.57 \pm 0.12^{\mathrm{ad}}$ & $0.95 \pm 0.03^{\mathrm{e}}$ \\
\hline
\end{tabular}

Values are mean $\pm S E M, n=3$

Values with different superscripts along the row are significantly different $(\mathrm{P}<0.05)$ 
Key: Blend $1=70 \%$ yellow maize: $30 \%$ soya bean

Blend $2=70 \%$ yellow maize: $30 \%$ pumpkin seed

Blend $3=70 \%$ yellow maize: $30 \%$ fish meal

Blend $4=70 \%$ yellow maize: $20 \%$ soya bean: $10 \%$ pumpkin seed

Blend $5=70 \%$ yellow maize: 15 soya bean: $15 \%$ fish meal

Blend $6=60 \%$ yellow maize: $20 \%$ pumpkin seed: $20 \%$ fish meal

$\mathrm{F}-100=$ formula 100 control therapeutic diet 
There were no significant $(\mathrm{P}>0.05)$ differences in the calcium levels of blends 1 and 3 , then 2 and 6 The $\mathrm{P}$ contents of all the food blends including the control food blend fall within the range of $0.01-0.02 \mathrm{ug} / \mathrm{g}$. Blend 2 had highest value for $\mathrm{Zn}$, followed very closely by blend 1 . There were significant $(\mathrm{P}<0.05)$ differences in the Fe contents of all the food blends, except blend 1 and 6 . The food blend 2 had a higher value for Fe, while blend 5 recorded the least value. The control blend (F-100) had the highest value for Fe when compared to the food blends. The food blend $1 \mathrm{had} 1.73 \mathrm{ug} / \mathrm{g}$ of $\mathrm{Cu}$, and is the highest value, while blend 3 had the least value for $\mathrm{Cu}(0.53 \pm 0.09 \mathrm{ug} / \mathrm{g})$.

\section{VITAMIN CONTENT OF THE INGREDIENTS AND THE FOOD BLENDS}

The vitamin content of unprocessed and processed yellow maize, soya bean and pumpkin seed and fish meal are presented in Table 6. There was a significant $(\mathrm{P}<0.05)$ increase in the $\mathrm{B}$ - group vitamins and vitamin $\mathrm{C}$ level of the fermented yellow maize, when compared to the unprocessed yellow maize. A significant $(\mathrm{P}<0.05)$ reduction in vitamins $\mathrm{A}$ and $\mathrm{E}$ were observed in the fermented yellow maize. Significant $(\mathrm{P}<0.05)$ reduction in vitamin $\mathrm{B}_{1}$ content of roasted soya bean and pumpkin seed was observed when compared to the unprocessed samples of soya bean and pumpkin seed. Vitamin $\mathrm{B}_{2}$ contents of the unprocessed soya bean and pumpkin seed are $10.87 \pm 1.20 \mathrm{ug} / \mathrm{g}$ and $1.47 \pm 0.03 \mathrm{ug} / \mathrm{g}$ respectively, while the roasted samples of soya bean and pumpkin seed recorded $7.54 \pm 0.34 \mathrm{ug} / \mathrm{g}$ and $1.47 \pm 0.03 \mathrm{ug} / \mathrm{g}$, respectively. The differences were significant $(\mathrm{P}<0.05)$. A significant $(\mathrm{P}<0.05)$ decrease was observed in the levels of vitamins $\mathrm{B}_{3}, \mathrm{~B}_{6}$ and $\mathrm{B}_{12}$ of the roasted samples of soya bean and pumpkin seed, when compared to the unprocessed samples of soya bean and pumpkin seed. Ascorbic acid and B group vitamins were not 
Table 6: Vitamin Content of Unprocessed and Processed Yellow maize, Soya bean, Pumpkin seed and Fish Meal Samples

\begin{tabular}{|c|c|c|c|c|c|c|c|c|}
\hline \multirow{2}{*}{$\begin{array}{l}\text { Vitamin } \\
(\mathrm{ug} / \mathrm{g})\end{array}$} & \multirow{2}{*}{\multicolumn{2}{|c|}{$\begin{array}{c}\text { Yellow maize } \\
\text { Unprocessed Fermented }\end{array}$}} & \multicolumn{2}{|c|}{ Soya bean } & \multicolumn{2}{|c|}{ Pumpkin seed } & \multicolumn{2}{|l|}{ Fish } \\
\hline & & & Unprocessed & Roasted & Unprocessed & Roasted & Fresh & Dried \\
\hline Vit. $B_{1}$ & $58.60 \pm 0.83^{b}$ & $63.36 \pm 0.36^{\mathrm{a}}$ & $8.33 \pm 0.09^{a}$ & $6.23 \pm 0.15^{\mathrm{b}}$ & $7.20 \pm 0.25^{\mathrm{a}}$ & $6.33 \pm 0.24^{b}$ & ND & ND \\
\hline Vit. $B_{2}$ & $1.97 \pm 0.12^{\mathrm{b}}$ & $2.22 \pm 0.36^{\mathrm{a}}$ & $10.87 \pm 1.20^{\mathrm{a}}$ & $7.54 \pm 0.37^{\mathrm{b}}$ & $2.420 .04^{\mathrm{a}}$ & $1.470 .03^{\mathrm{b}}$ & ND & ND \\
\hline Vit. $B_{3}$ & $9.83 \pm 0.19^{b}$ & $15.37 \pm 0.01^{\mathrm{a}}$ & $6.490 .63^{\mathrm{a}}$ & $5.59 \pm 0.21^{\mathrm{b}}$ & $9.83 \pm 0.27^{b}$ & $11.10 \pm 0.67^{\mathrm{a}}$ & ND & ND \\
\hline Vit. B6 & $1.26 \pm 0.03^{\mathrm{a}}$ & $0.39 \pm 0.01^{b}$ & $4.70 \pm 0.08^{\mathrm{a}}$ & $3.83 \pm 0.01^{\mathrm{b}}$ & $2.32 \pm 0.01^{\mathrm{a}}$ & $1.830 .01^{\mathrm{b}}$ & ND & ND \\
\hline Vit. $B_{12}$ & $2.66 \pm 0.02^{\mathrm{a}}$ & $2.73 \pm 0.02^{\mathrm{a}}$ & $1.720 .03^{\mathrm{a}}$ & $1.33 \pm 0.06^{\mathrm{a}}$ & $0.23 \pm 0.01^{\mathrm{a}}$ & $0.11 \pm 0.01^{\mathrm{b}}$ & ND & ND \\
\hline Vit C & $41.29 \pm 0.04^{b}$ & $48.86 \pm 0.37^{\mathrm{a}}$ & $0.33 \pm 0.01^{\mathrm{a}}$ & $0.23 \pm 0.01^{\mathrm{b}}$ & $2.25 \pm 0.01^{\mathrm{a}}$ & $1.22 \pm 0.01^{\mathrm{b}}$ & ND & ND \\
\hline Vit A & $0.81 \pm 0.03^{\mathrm{a}}$ & $0.55 \pm 0.01^{\mathrm{b}}$ & $1.35 \pm 0.01^{\mathrm{a}}$ & $1.36 \pm 0.02^{\mathrm{a}}$ & $0.10 \pm 0.00^{\mathrm{a}}$ & $0.97 \pm 0.01^{\mathrm{a}}$ & $3.42 \pm 0.01^{\mathrm{a}}$ & $2.18 \pm 0.02^{b}$ \\
\hline Vit E & $8.68 \pm 0.23^{\mathrm{a}}$ & $8.71 \pm 0.01^{\mathrm{a}}$ & $14.47 \pm 0.01^{\mathrm{b}}$ & $15.50 \pm 0.24^{\mathrm{a}}$ & $1.68 \pm 0.30^{\mathrm{a}}$ & $0.92 \pm 0.06^{\mathrm{b}}$ & $10.71 \pm 0.01^{\mathrm{a}}$ & $8.98 \pm 0.02^{b}$ \\
\hline
\end{tabular}

\section{Values are mean \pm SEM, $n=3$}

Values with different superscript along the row under the same heading, are significantly different $(\mathrm{P}<0.05)$

Key: ND = Not detected. 
detected in fish samples. However, a significant $(\mathrm{P}<0.05)$ reduction in vitamins $\mathrm{A}$ and $\mathrm{E}$ content was observed in the dried fish sample.

The vitamin levels of the food blends were presented in Table 7 The food blend 2 recorded the highest level of vitamin $\mathrm{B}_{1}(93.23 \pm 0.23 \mathrm{ug} / \mathrm{g})$, followed by Blend $1(81.38 \pm 0.37 \mathrm{ug} / \mathrm{g})$. All the food blends recorded a lower value for vitamin $\mathrm{B}_{1}$ when compared to the control food blend (F-100) that recorded $116 \pm 0.63 \mathrm{ug} / \mathrm{g}$. The food blend $1 \mathrm{had} 2.39 \pm 0.19 \mathrm{ug} / \mathrm{g}$ as its vitamin $\mathrm{B}_{2}$ content, and this value was significantly $(\mathrm{P}<0.05)$ higher when compared with all the food blends, except the control food blend, that had recorded $3.03 \pm 0.09 \mathrm{ug} / \mathrm{g}$. There was significant $(\mathrm{P}<0.05)$ difference in vitamins $\mathrm{B}_{3}$ and $\mathrm{B}_{6}$ levels of all the food blends. The vitamin $B_{12}$ levels of the food blends showed that the food blend 2 had a highest value, followed closely by Blend 1, while the food Blend 3 recorded the least value for vitamin $\mathrm{B}_{12}$ content. The vitamin $\mathrm{B}_{12}$ levels of food Blend 3 was higher than the control food Blend (F-100), while the remaining food blends have lower level of vitamin $\mathrm{B}_{12}$, than the control food Blend (F-100). There was no significant ( $\mathrm{P}>0.05$ ) difference in the ascorbic acid (Vitamin $\mathrm{C}$ ) level of food blends 1,2,4 and 5, while a significant $(\mathrm{P}<0.05)$ difference was observed when compared with Blend 3. The control food blend $(\mathrm{F}-100)$ recorded a highest value of ascorbic acid, when compared to the food blends. The food blend 5 recorded a higher value for Vitamin A, followed closely by Blend 1, however, the difference is not significant ( $\mathrm{P}>0.05)$. The vitamin A level of food blend 3 is comparable to the control food blend (F-100). Food blend 3 recorded $3.94 \pm 0.01 \mathrm{ug} / \mathrm{g}$ for vitamin $\mathrm{E}$, which is the highest value, while food blend 1 recorded a least value for vitamin E. The vitamin E level of Food blend 2 is $0.63 \pm 0.02 \mathrm{ug} / \mathrm{g}$, while that of the food blends 4,5 and 6 are 0.84 $\pm 0.02,0.49 \pm 0.03$ and $0.98 \pm 0.01 \mathrm{ug} / \mathrm{g}$ respectively. The difference was 
Table 7: Vitamin Contents of Food Blends $(\mu \mathrm{g} / \mathrm{g})$

\begin{tabular}{|c|c|c|c|c|c|c|c|}
\hline & Blend 1 & Blend 2 & Blend 3 & Blend 4 & Blend 5 & Blend6 & F-100 \\
\hline Vit.B 1 & $81.38 \pm 0.37^{c}$ & $93.23 \pm 0.25^{b}$ & $59.53 \pm 1.14^{\mathrm{e}}$ & $51.76 \pm 0.84^{\mathrm{f}}$ & $61.23 \pm 0.53^{\mathrm{de}}$ & $62.70 \pm 0.30^{\mathrm{d}}$ & $116.10 \pm 0.63^{\mathrm{a}}$ \\
\hline Vit.B ${ }_{2}$ & $2.39 \pm 0.17^{\mathrm{b}}$ & $1.55 \pm 0.25^{\mathrm{c}}$ & $0.78 \pm 0.08^{\mathrm{d}}$ & $0.79 \pm 0.03^{\mathrm{d}}$ & $0.89 \pm 0.01^{\mathrm{d}}$ & $0.98 \pm 0.03^{\mathrm{d}}$ & $3.03 \pm 0.09^{\mathrm{a}}$ \\
\hline Vit.B $_{3}$ & $11.24 \pm 0.01^{\mathrm{c}}$ & $7.20 \pm 0.03^{\mathrm{f}}$ & $5.83 \pm 0.11^{\mathrm{g}}$ & $12.74 \pm 0.01^{\mathrm{b}}$ & $10.85 \pm 0.02^{\mathrm{d}}$ & $9.08 \pm 0.01^{\mathrm{e}}$ & $12.98 \pm 0.02^{\mathrm{a}}$ \\
\hline Vit.B6 & $9.89 \pm 0.03^{b}$ & $6.39 \pm 0.00^{\mathrm{e}}$ & $4.70 \pm 0.01^{\mathrm{g}}$ & $7.46 \pm 0.02^{\mathrm{d}}$ & $8.22 \pm 0.11^{\mathrm{c}}$ & $5.65 \pm 0.01^{\mathrm{f}}$ & $11.40 \pm 0.34^{\mathrm{a}}$ \\
\hline Vit.B12 & $6.20 \pm 0.52^{\mathrm{b}}$ & $10.23 \pm 1.74^{\mathrm{a}}$ & $3.41 \pm 0.19^{d}$ & $2.80 \pm 0.29^{\mathrm{e}}$ & $2.90 \pm 0.87^{\mathrm{f}}$ & $2.15 \pm 0.55^{\mathrm{f}}$ & $5.63 \pm 0.75^{\mathrm{c}}$ \\
\hline Vit. C & $3.27 \pm 0.01^{\mathrm{c}}$ & $3.54 \pm 0.01^{\mathrm{c}}$ & $2.60 \pm 0.01^{\mathrm{d}}$ & $3.15 \pm 0.03^{c}$ & $3.17 \pm 0.02^{\mathrm{c}}$ & $4.06 \pm 0.03^{\mathrm{b}}$ & $4.53 \pm 0.18^{\mathrm{a}}$ \\
\hline Vit. A & $1.34 \pm 0.01^{\mathrm{a}}$ & $0.14 \pm 0.02^{\mathrm{e}}$ & $0.94 \pm 0.01^{\mathrm{c}}$ & $0.45 \pm 0.02^{\mathrm{d}}$ & $1.35 \pm 0.01^{\mathrm{a}}$ & $1.04 \pm 0.01^{\mathrm{b}}$ & $0.98 \pm 0.01^{\mathrm{c}}$ \\
\hline Vit. E & $0.45 \pm 0.01^{\mathrm{a}}$ & $0.63 \pm 0.02^{\mathrm{a}}$ & $3.94 \pm 0.01^{\mathrm{b}}$ & $0.84 \pm 0.02^{\mathrm{c}}$ & $0.49 \pm 0.03+$ & $0.98 \pm 0.01^{\mathrm{d}}$ & $0.61 \pm 0.06^{\mathrm{a}}$ \\
\hline
\end{tabular}

Values are mean \pm SEM, $n=3$

Values with different superscript along the row are significantly different $(\mathbf{P}<0.05)$

Key: Blend $1=70 \%$ yellow maize: $30 \%$ soya bean

Blend $2=70 \%$ yellow maize: $30 \%$ pumpkin seed

Blend $3=70 \%$ yellow maize: $30 \%$ fish meal

Blend $4=70 \%$ yellow maize: $20 \%$ soya bean: $10 \%$ pumpkin seed

Blend $5=70 \%$ yellow maize: 15 soya bean: $15 \%$ fish meal

Blend $6=60 \%$ yellow maize: $20 \%$ pumpkin seed: $20 \%$ fish meal

F-100 $=$ formula 100 control therapeutic diet 
significant $(\mathrm{P}<0.05)$. The vitamin $\mathrm{E}$ level of food blend $6(0.98 \pm 0.01 \mathrm{ug} / \mathrm{g})$ was higher than that of the control group $(0.61 \pm 0.06 \mathrm{ug} / \mathrm{g})$, while that of the food blend $2(0.63 \pm 0.02 \mathrm{ug} / \mathrm{g})$ is comparable to that of the control group $(0.61 \pm 0.06 \mathrm{ug} / \mathrm{g})$.

\section{AMINO ACID PROFILE OF THE INGREDIENTS AND THE FOOD BLENDS}

Table 8 presents the amino acid profile of unprocessed and processed samples of yellow maize, soya bean, pumpkin seed and fish meal. A significant $(\mathrm{P}<0.05)$ decrease was recorded in the leucine content of the fermented maize $1.43 \pm 0.02 \mathrm{~g} / 100 \mathrm{~g}$, while no significant $(\mathrm{P}>0.05)$ difference was recorded in the leucine contents of the unprocessed and processed samples of soya bean and pumpkin seed when compared to processed soya bean and pumpkin seed. There were significant $(\mathrm{P}<0.05)$ increase in the phenylalanine contents of the processed yellow maize, when compared to unprocessed yellow maize. Soya bean and pumpkin seed also follow similar pattern. A significant $(\mathrm{P}<0.05)$ increase was observed in the valine, methionine and proline contents of the fermented yellow maize, when compared to the unprocessed yellow maize. A significant $(\mathrm{P}<0.05)$ reduction of these amino acids was observed in processed soya bean and pumpkin seed when compared to the unprocessed samples of soya bean and pumpkin seed. There were significant $(\mathrm{P}<0.05)$ increase in the remaining amino acid contents of the fermented yellow maize, when compared to the unprocessed sample of the yellow maize. However, a significant $(\mathrm{P}<0.05)$ reduction of these amino acids were observed in the roasted samples of soya bean and pumpkin seed, except aspartic acid, where the difference was not significant $(\mathrm{P}>0.05)$. The levels of amino acid contents of the dried fish samples were higher than that of the unprocessed type. The differences were statistically significant $(\mathrm{P}<0.05)$. 
Table 8: Amino Acid Profile of Unprocessed and Processed Yellow Maize, Soya bean, Pumpkin Seed and Fish Meal

\begin{tabular}{|c|c|c|c|c|c|c|c|c|}
\hline \multirow{2}{*}{$\begin{array}{l}\text { Amino acid } \\
(\mathrm{g} / 100 \mathrm{~g})\end{array}$} & \multicolumn{2}{|c|}{ Yellow maize } & \multicolumn{2}{|c|}{ Soya beans } & \multicolumn{2}{|c|}{ Pumpkin seeds } & \multicolumn{2}{|l|}{ Fish } \\
\hline & Unprocessed & Fermented & Unprocessed & Roasted & Unprocessed & Roasted & Fresh & Dried \\
\hline Leucine & $3.26 \pm 0.02^{\mathrm{a}}$ & $1.43 \pm 0.02^{\mathrm{b}}$ & $5.02 \pm 0.01^{b}$ & $4.89 \pm 0.60^{\mathrm{a}}$ & $4.28 \pm 0.02^{\mathrm{a}}$ & $4.21 \pm 0.02^{\mathrm{a}}$ & $4.95 \pm 0.02^{\mathrm{b}}$ & $5.42 \pm 0.01^{\mathrm{a}}$ \\
\hline Lysine & $1.26 \pm 0.02^{\mathrm{b}}$ & $1.43 \pm 0.01^{\mathrm{a}}$ & $3.76 \pm 0.03^{\mathrm{a}}$ & $3.37 \pm 0.02^{\mathrm{a}}$ & $2.21 \pm 0.02^{\mathrm{a}}$ & $2.22 \pm 0.01^{\mathrm{a}}$ & $3.95 \pm 0.02^{b}$ & $4.25 \pm 0.02^{\mathrm{a}}$ \\
\hline Isoleucine & $1.07 \pm 0.02^{\mathrm{b}}$ & $2.37 \pm 0.02^{\mathrm{a}}$ & $2.37 \pm 0.01^{\mathrm{a}}$ & $2.35 \pm 0.01^{\mathrm{a}}$ & $2.00 \pm 0.01^{\mathrm{a}}$ & $1.77 \pm 0.03^{\mathrm{b}}$ & $2.00 \pm 0.02^{\mathrm{b}}$ & $2.25 \pm 0.12^{\mathrm{a}}$ \\
\hline Phenylalanine & $1.68 \pm 0.01^{b}$ & $1.79 \pm 0.02^{\mathrm{a}}$ & $3.19 \pm 0.01^{\mathrm{a}}$ & $2.97 \pm 0.02^{\mathrm{b}}$ & $2.74 \pm 0.02^{\mathrm{a}}$ & $2.44 \pm 0.03^{\mathrm{b}}$ & $2.97 \pm 0.01^{\mathrm{b}}$ & $3.27 \pm 0.02^{\mathrm{a}}$ \\
\hline Tryptophan & $0.13 \pm 0.03^{b}$ & $0.18 \pm 0.03^{\mathrm{a}}$ & $1.47 \pm 0.02^{b}$ & $1.55 \pm 0.03^{\mathrm{a}}$ & $1.15 \pm 0.04^{\mathrm{a}}$ & $0.98 \pm 0.01^{\mathrm{b}}$ & $1.21 \pm 0.02^{\mathrm{b}}$ & $2.39 \pm 0.01^{\mathrm{a}}$ \\
\hline Valine & $1.47 \pm 0.02^{b}$ & $1.96 \pm 0.02^{\mathrm{a}}$ & $2.39 \pm 0.03^{\mathrm{a}}$ & $2.33 \pm 0.01^{\mathrm{a}}$ & $1.40 \pm 0.02^{\mathrm{a}}$ & $1.24 \pm 0.02^{\mathrm{b}}$ & $2.05 \pm 0.01^{\mathrm{b}}$ & $2.87 \pm 0.02^{\mathrm{a}}$ \\
\hline Methionine & $0.48 \pm 0.02^{\mathrm{a}}$ & $0.49 \pm 0.01^{\mathrm{a}}$ & $1.06 \pm 0.02^{\mathrm{a}}$ & $0.10 \pm 0.01^{\mathrm{a}}$ & $0.78 \pm 0.03^{\mathrm{a}}$ & $0.69 \pm 0.01^{\mathrm{b}}$ & $1.01 \pm 0.12^{\mathrm{b}}$ & $1.92 \pm 0.01^{\mathrm{a}}$ \\
\hline Proline & $0.12 \pm 0.01^{\mathrm{a}}$ & $0.17 \pm 0.01^{b}$ & $2.55 \pm 0.02^{\mathrm{a}}$ & $2.09 \pm 0.01^{\mathrm{b}}$ & $2.04 \pm 0.03^{\mathrm{a}}$ & $1.98 \pm 0.01^{\mathrm{a}}$ & $2.00 \pm 0.01^{\mathrm{b}}$ & $2.36 \pm 0.11^{\mathrm{a}}$ \\
\hline Arginine & $3.13 \pm 0.02^{\mathrm{a}}$ & $3.36 \pm 0.02^{\mathrm{b}}$ & $5.34 \pm 0.02^{\mathrm{a}}$ & $5.34 \pm 0.02^{\mathrm{a}}$ & $3.27 \pm 0.01^{\mathrm{a}}$ & $3.24 \pm 0.01^{\mathrm{a}}$ & $4.39 \pm 0.01^{\mathrm{b}}$ & $5.32 \pm 0.01^{\mathrm{a}}$ \\
\hline Tyrosine & $1.09 \pm 0.01^{\mathrm{a}}$ & $1.26 \pm 0.02^{\mathrm{b}}$ & $3.13 \pm 0.01^{\mathrm{a}}$ & $2.97 \pm 0.01^{\mathrm{a}}$ & $2.49 \pm 0.01^{\mathrm{a}}$ & $2.48 \pm 0.02^{\mathrm{a}}$ & $2.03 \pm 0.01^{\mathrm{b}}$ & $2.95 \pm 0.01^{\mathrm{a}}$ \\
\hline Histidine & $1.43 \pm 0.65^{\mathrm{a}}$ & $0.99 \pm 0.09^{b}$ & $1.64 \pm 0.02^{\mathrm{a}}$ & $1.59 \pm 0.01^{\mathrm{a}}$ & $1.54 \pm 0.02^{\mathrm{a}}$ & $1.38 \pm 0.02^{\mathrm{a}}$ & $1.45 \pm 0.10^{\mathrm{a}}$ & $1.47 \pm 0.01^{\mathrm{a}}$ \\
\hline Cystine & $0.33 \pm 0.01^{\mathrm{a}}$ & $0.35 \pm 0.01^{\mathrm{a}}$ & $0.98 \pm 0.01^{\mathrm{a}}$ & $0.96 \pm 0.01^{\mathrm{a}}$ & $6.39 \pm 0.01^{\mathrm{a}}$ & $6.23 \pm 0.01^{\mathrm{a}}$ & $0.98 \pm 0.01^{\mathrm{b}}$ & $1.04 \pm 0.01^{\mathrm{a}}$ \\
\hline Alanine & $1.85 \pm 0.03^{\mathrm{a}}$ & $1.87 \pm 0.02^{\mathrm{a}}$ & $4.21 \pm 0.01^{\mathrm{a}}$ & $3.20 \pm 0.01^{\mathrm{b}}$ & $1.69 \pm 0.01^{\mathrm{a}}$ & $1.37 \pm 0.01^{\mathrm{b}}$ & $2.97 \pm 0.01^{\mathrm{b}}$ & $3.04 \pm 0.02^{\mathrm{a}}$ \\
\hline Glutamic acid & $4.20 \pm 0.01^{\mathrm{a}}$ & $4.29 \pm 0.01^{\mathrm{a}}$ & $1.65 \pm 0.02^{\mathrm{a}}$ & $1.25 \pm 0.03^{\mathrm{b}}$ & $1.19 \pm 0.01^{\mathrm{a}}$ & $1.03 \pm 0.01^{\mathrm{b}}$ & $9.85 \pm 0.01^{\mathrm{b}}$ & $10.36 \pm 0.10^{a}$ \\
\hline Threonine & $0.65 \pm 0.03^{b}$ & $0.77 \pm 0.01^{\mathrm{a}}$ & $1.65 \pm 0.02^{\mathrm{a}}$ & $1.25 \pm 0.03^{\mathrm{b}}$ & $1.19 \pm 0.01^{\mathrm{a}}$ & $1.03 \pm 0.01^{\mathrm{b}}$ & $2.76 \pm 0.12^{\mathrm{b}}$ & $2.67 \pm 0.01^{\mathrm{a}}$ \\
\hline Serine & $0.28 \pm 0.01^{\mathrm{a}}$ & $0.32 \pm 0.01^{\mathrm{a}}$ & $2.76 \pm 0.02^{\mathrm{a}}$ & $1.63 \pm 0.01^{\mathrm{b}}$ & $1.21 \pm 0.01^{\mathrm{a}}$ & $1.11 \pm 0.05^{\mathrm{b}}$ & $2,20 \pm 0.01^{\mathrm{b}}$ & $2.29 \pm 0.02^{\mathrm{a}}$ \\
\hline Aspartic acid & $3.42 \pm 0.01^{\mathrm{a}}$ & $3.44 \pm 0.02^{\mathrm{a}}$ & $4.48 \pm 0.02^{\mathrm{a}}$ & $4.46 \pm 0.02^{\mathrm{a}}$ & $2.97 \pm 0.01^{\mathrm{a}}$ & $2.51 \pm 0.03^{\mathrm{b}}$ & $6.03 \pm 0.01^{\mathrm{b}}$ & $6.35 \pm 0.01^{\mathrm{a}}$ \\
\hline
\end{tabular}


Table 9 present the amino acid profile of the food blends and the control diet. The food blend 6 had the highest leucine $(9.55 \pm 0.05 \mathrm{~g} / 100 \mathrm{~g})$ and lysine $(6.87 \pm 0.01 \mathrm{~g} / 100 \mathrm{~g})$ contents, closely followed by Blend 5 with leucine and lysine contents of $9.28 \pm 0.02 \mathrm{~g} / 100 \mathrm{~g}$ and $6.47 \pm 0.01 \mathrm{~g} / 100 \mathrm{~g}$, respectively, while Blend 4 recorded a least value for leucine $6.77 \pm 0.01 \mathrm{~g} / 100 \mathrm{~g}$ and lysine $5.03 \pm 0.02 \mathrm{~g} / 100 \mathrm{~g}$. The control food blend $(\mathrm{F}-100)$ recorded the least value for lysine when compared to the food blends. The food blend 6 had highest isoleucine value $(4.22 \pm 0.02 \mathrm{~g} / 100 \mathrm{~g})$, followed by food blend 5 ( $3.98 \pm 0.02 \mathrm{~g} / 100 \mathrm{~g})$. The food blend 4 recorded the least value for isoleucine. The prepared food blends recorded higher values for isoleucine, compared to the control blend. There was no significant $(\mathrm{P}>0.05)$ difference in the isoleucine levels of food blend 4 and that of the control. There were significant $(\mathrm{P}<0.05)$ differences in the phenylalanine contents of the food blends 1 and 3, and 5 and control diet, with blend 6 having the highest value of $5.68 \pm 0.01 \mathrm{~g} / 100 \mathrm{~g}$, followed closely by blend $5(5.15 \pm 0.03 \mathrm{~g} / 100 \mathrm{~g})$. The control food blend (F-100) had a value of $5.14 \pm 0.02 \mathrm{~g} / 100 \mathrm{~g}$ phenylalanine content. Nor leucine was not detected in all the samples. The tryptophan levels of all the prepared food blends are comparable to that of the control blend. There was significant $(\mathrm{P}<0.05)$ difference in the tryptophan levels of All the food blends. The food blend 4 recorded the lowest value for tryptophan. The valine level of the control blend was significantly $(\mathrm{P}<0.05)$ higher than all the prepared blends. Among the food blends, blend 6 had the highest value $(4.56 \pm 0.03 \mathrm{~g} / 100 \mathrm{~g})$, followed by blend $5(4.33 \pm 0.03 \mathrm{~g} / 100 \mathrm{~g})$. There was no significant $(\mathrm{P}<0.05)$ difference in the valine levels of food blend $1(3.62 \pm 0.12 \mathrm{~g} / 100 \mathrm{~g})$ and blend $4(3.68 \pm 0.01 \mathrm{~g} / 100 \mathrm{~g})$. However, the food blend $1(3.62 \pm 0.12 \mathrm{~g} / 100 \mathrm{~g})$ recorded the least value for valine. Blend 6 recorded highest value for methionine, when compared to the food blends, but lower than the methionine content of the control food blend (F-100). 
Table 9: Amino Acid Profile of food blends

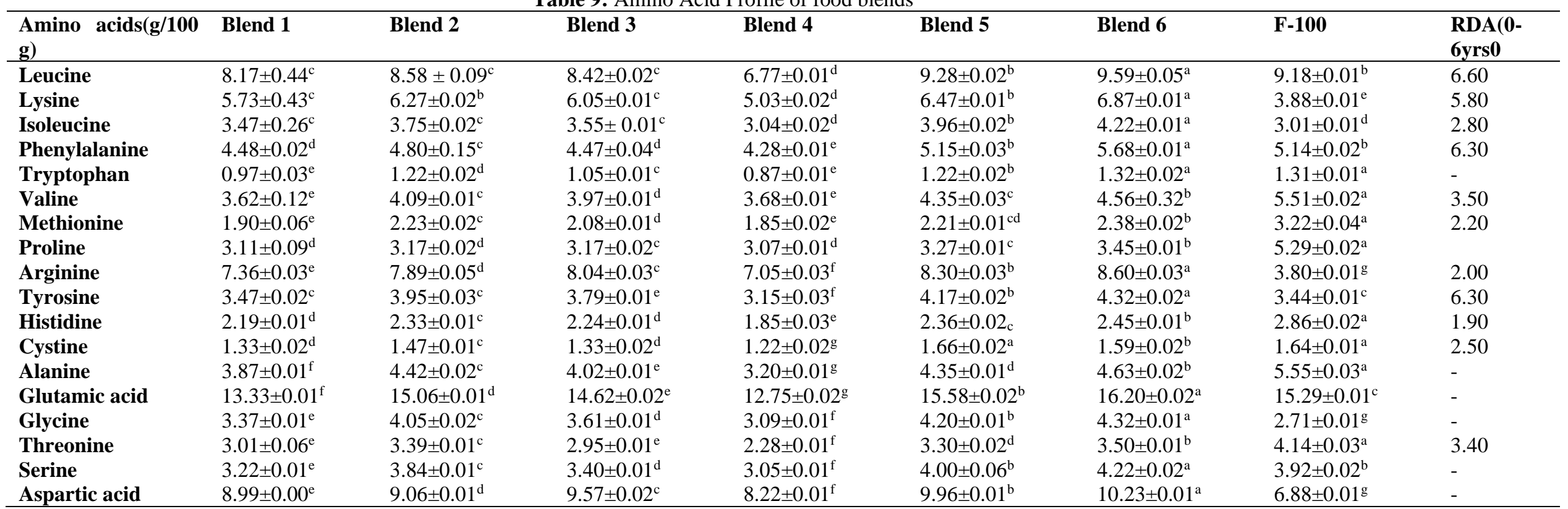

Values are mean \pm SEM, $n=3$

Values with different superscript along the row are significantly different $(\mathbf{P}<\mathbf{0 . 0 5})$

Key: Blend $1=70 \%$ yellow maize: $30 \%$ soya bean

Blend $2=70 \%$ yellow maize: $30 \%$ pumpkin seed

Blend $3=70 \%$ yellow maize: $30 \%$ fish meal

Blend $4=70 \%$ yellow maize: $20 \%$ soya bean: $10 \%$ pumpkin seed

Blend $5=70 \%$ yellow maize: 15 soya bean: $15 \%$ fish meal

Blend $6=60 \%$ yellow maize: $20 \%$ pumpkin seed: $20 \%$ fish meal

F-100 $=$ formula 100 control therapeutic diet

RDA $=$ Recommended Daily Allowance 
There was no significant $(\mathrm{P}>0.05)$ difference in the proline content of blend $1(3.11 \pm 0.09 \mathrm{~g} / 100 \mathrm{~g})$, blend $2(3.17 \pm 0.02$ $\mathrm{g} / 100 \mathrm{~g})$, blend $3(3.17 \pm 0.02 \mathrm{~g} / 100 \mathrm{~g})$ and food blend $4(3.07 \pm 0.01 \mathrm{~g} / 100 \mathrm{~g})$. The control food blend $(\mathrm{F}-100)$ had the highest value of proline when compared to the food blends. There was significant $(\mathrm{P}<0.05)$ difference in the Arginine and Tyrosine content of the food blends. There was significant $(\mathrm{P}<0.05)$ difference in alanine, glutamic acid and glycine levels of the food blends when compared within the blend and the control food blend (F-100). Blend 6 had highest value $(3.50 \pm 0.01 \mathrm{~g} / 100 \mathrm{~g})$ for threonine, while blend 4 recorded the least value. The threonine levels of all the food blends were lower than that of the control food blend ( $F-100)$. There was significant $(\mathrm{P}<0.05)$ difference in serine and aspartic acid levels of the food blends including the control blend (F-100).

\section{DISCUSSION}

\section{PROXIMATE COMPOSITION OF THE INGREDIENTS AND FOOD BLENDS}

The moisture contents of the fermented yellow maize, roasted soya bean and pumpkin seed were lower, compared to the unprocessed samples of yellow maize, soya bean and pumpkin seed. The low moisture content might be due to the drying and roasting of the sample, and this implies that food blends from this source will have a low moisture, and better shelf life. This agrees with similar work reported by $(19,20)$, who observed that low moisture content levels in food blends can support a longer shelf life. This is because food spoilage microorganisms thrive where moisture contents of food are very high.

The decrease observed in the protein content during fermentation of yellow maize was attributed to a possible increase in the number of microorganisms that use protein for metabolism. During fermentation and germination, microorganism hydrolyze protein and its complexes to release free amino acid for synthesis of new proteins. This agrees with the findings of Modu et al. (2010), Frazier and Westhoff (1978), Gernah et al. (2011), Onweluzo and Nwabugwu (2009) and Laminu et al. (2014). The process of roasting of the soya bean and pumpkin seed did not have effect on their protein content and this is in agreement with the report of $(24,25)$. Increase in protein content of dried fish observed might be attributed to the significant decrease in the moisture content during drying, which leads to significant increase in nutrient density (Modu et al., 2015).

The decrease in ash contents of the fermented yellow maize, roasted soya bean and pumpkin seed and dried fish might be due to the processing methods used. Although the percentage ash content falls within the ranged (1.4$3.3 \%$ ) reported for maize (Modu et al., 2010).

The decrease in the fat content of the fermented yellow maize might be due to the increased activities of the lipolytic enzymes which hydrolyzed fat to fatty acid and glycerol. Similar observation was made by (Modu et al., 2012), who reported decrease in total fat contents of fermented pear millet and germinated wheat. The decrease in the total fat contents of roasted soya bean and pumpkin seed may be due to loss of volatile matter in the open dry heat processing (Falmata et al., 2014).

The fibre levels of fermented maize and roasted soya bean and pumpkin seed were significantly reduced compared to the unprocessed samples. This is in accordance with the report of Mbaeyi and Onweluzo (2010), who reported that the reduction in fibre levels could be due to retro gradation of starch during processing (Nout, 1999), and 
Bintu et al. (2015) reported similar findings. Fibre content was not detected in fish. This agrees with the finding of Bernard (2016).

The food blends had moisture contents within the moisture content of dried food (3.6\%). The low moisture contents observed is a good indicator of their potential to have longer shelf life. This is in accordance with the findings of Adebayo (2012). The low moisture content of food products inhibits biochemical activities of invading microorganisms and therefore, prevents food spoilage during storage (Ijarotimi and Kashinro, 2013).

The protein content of the food blends 3, 5 and 6 are higher than that of the control blend. This could be attributed to the inclusion of fish in the blends. Fish is a rich source of protein, and as such, can be used to complement the protein content of the legumes used so as to boost the protein quality of the food blends. This agrees with report of Bintu (2015), who reported increase in the protein content of food blends after inclusion of animal protein (Cray fish). The blending of two or more cereals and legumes with fish meal to complement each other is a key feature of food formulation, which also enhanced the protein quality of the food blends. The high protein contents of these blends are as a result of the addition of certain percentage of fish meal. According to FAO/WHO Codex Alimentarius standard for food blends, the protein contents of food blend should range from $14.52-37.70 \mathrm{~g} / 100 \mathrm{~g}$ for maximum complementation of amino acid in food and growth ${ }^{45}$. Thus, the formulations 3,4 , and 6 satisfy the protein demand of malnourished individuals.

The fat contents of the food blends correspond to the recommended fat levels for malnourished individuals which should be less than $10 \%$. The relatively low-fat content of the composite blends makes them suitable raw materials in the formulation of a variety of food products for the elderly. The fat contents of a food can affect its shelflife stability. This is because fat can undergo oxidative deterioration, which leads to food spoilage. Hence, the food blend with a high fat content is more liable to spoilage than one with o lower fat content. However, the fat content of food blend 1, is comparable to the fat content of the control diet. The fat contents of all the food blends fall within the RDA range of infants 0-1 Year.

High dietary fibre contents have been reported to impair protein and mineral digestion and absorption in human nutrition (Bernard et al., 2016). Hence, low fibre blend is suitable for the management of kwashiorkor which requires adequate intake of protein and mineral. All the food blends exhibited low fibre contents, and are within the FAO/WHO limits of $<5 \%$, except blend 5 , which was slightly above the limit, this might be due to addition of pumpkin seed, which was reported to have high fibre content (USDA, 2020).

The carbohydrate contents of the food blends and the control blend were higher than the lower limit for carbohydrates (41.3-73.79 g/100g) of the Codex Alimentarius standard (Ijarotimi and Kashinro, 2013).

For all the food blends, both prepared and the control, the energy density per 100g of the dry food was lower than the maximum energy $(483.9 \mathrm{Kcal} / 100 \mathrm{~g} / 100 \mathrm{~g})$ recommended in the Codex Alimentarius standard for weaning foods ((Ijarotimi and Kashinro, 2013).

\section{MINERAL COMPOSITION}

The loss in the level of sodium, potassium, magnesium, calcium, phosphorus, zinc and copper level in the processed samples could be attributed to the loss in the ash contents during fermentation. Similar work reported that more than $50 \%$ of the ash in sorghum was leached out of the steep water and washed away (Oyarekua and Eleyinmi, 2004; 
Akingbala, 1981). A decrease in the levels of $\mathrm{Na}, \mathrm{K}, \mathrm{Mg}, \mathrm{Ca}, \mathrm{P}, \mathrm{Zn}$ and $\mathrm{Fe}$ levels in processed samples were reported $(19,20)$.

The lower levels of $\mathrm{Ca}, \mathrm{P}, \mathrm{Zn}$, and $\mathrm{Fe}$ in the food blends 1- 6 when compared with control diet could be attributed to the fact that control weaning foods are usually fortified with micronutrient in order to meet FAO/ WHO guidelines for infant complementary formulation. The level of $\mathrm{Na}, \mathrm{K}, \mathrm{Mg}$ and $\mathrm{Cu}$ in food Blend 2 was higher than the control diet. This could be attributed to incorporation of pumpkin seed in the blend. Higher mineral element levels in pumpkin seed were reported (USDA, 2020). The Fe level of the food blend 2 is above the RDA for children between the ages of 0-6 month.

\section{VITAMIN}

Fermentation of yellow maize, roasting of soya bean and pumpkin seed caused significant increase in the levels of the B- group vitamins. This might the attributed to the fact that fermentation and roasting cause significant reduction in the antinutritional factors in cereals and legumes. Similar work reported that reduction in antinutrent levels improves the B-group vitamin (Bintu et al., 3015). This is also in accordance with the report (Agunbiade et al., 2013). Elemo et al., also reported increase in concentration in Niacin $\left(\left(B_{3}\right)\right.$, thiamine $\left(B_{1}\right)$, riboflavin $\left(B_{6}\right)$ and other vitamins in sorghum after fermentation. The decrease in vitamin $\mathrm{A}$ and $\mathrm{E}$ observed in roasted samples of soya bean and pumpkin seed might be attributed to the fact that vitamin $\mathrm{A}$ is light sensitive, while vitamin $\mathrm{C}$ is heat labile. Heat generated during roasting lead to loss in some parts of these vitamins (Elemo et al., 2013).

The B-group vitamins observed in the food blends were lower than the control diet, but higher than the RDA for 0-6-year-old child. Vitamin C level of food blend 6 is lower than that of control diet. However, it met up to $90 \%$ of the RDA for $0-6$ years old. The most prominent role of vitamin $\mathrm{C}$ is its immune stimulating effects which is important for the defense against infection. It acts as a powerful antioxidant that neutralizes harmful free radicals. It aids wound healing and iron absorption. Vitamin A and E contents of the samples increased with increased substitution of fish flour. The increase in the vitamin content of the formulations confirms the beneficial effects of supplementation (Okaka and Potter, 1977). Vitamin E is an important vitamin required for proper function of many organs in the body. It is also an antioxidant which protects the body tissue from damage caused by substances called free radical that harm the cell tissue and organs (42)

\section{AMINO ACID}

The increase observed in some of the essential amino acids of fermented flour of yellow maize could be attributed to the activities of some microorganisms that convert some of the nutrients in the food into amino acids for their utilization during fermentation period. Contrary, the lost in leucine due to fermentation could be attributed to the fact that those amino acids were utilized by the fermenting seed. This is in accordance with similar findings of (39), who reported that an increase in amino acid during fermentation might be due to the breakdown of other nutrients such as carbohydrate to synthesize amino acid that fermenting seed needed for its biochemical activities and growth. The decrease in the amino acids of the roasted soya bean and pumpkin seed might be due to denaturation of the protein content of the samples due to heat during roasting. The increase in amino acid contents of the dried fish is expected because drying reduces moisture contents and increases nutrient dense. Similar work reported on the increased levels of protein and other proximate parameters of dried onion cultivars (26). 
The increase in the levels of amino acids observed in the food blends were due to blending with multiple legumes and animal protein from fish. It was reported that fortification of maize with powdered unfermented locust bean increased the protein contents as well as protein quality essentially lacking in cereal grain (40). The finding of this study is also in agreement with earlier report (41) who reported that fortification of wheat flour (cereal) with soy protein increases protein quality by improving amino acid profile. The food blends 5 and 6 were boosted more in terms of Leucine, phenylalanine, lysine, probably due to supplementation with multiple legumes (soya bean and pumpkin seed) and fish flour which are rich source of protein.

\section{CONCLUSION}

This study showed that it is feasible to formulate high protein diets from yellow maize; which supplies the bulk of the energy, soya bean and pumpkin seeds which supplement one another for protein and micronutrients, and finally fish which contains decosahexaenoic acid (DHA), an essential omega-3 fatty acid which is vital for brain health in addition to the presence of vitamins A and E. The decosahexaenoic acid (DHA) is lacking in both the legumes/seeds.

\section{CONFLICT OF INTEREST}

The authors declare no conflict of interest.

\section{REFERENCES}

Adebayo-Oyetoro D. A., Olatidoye O. P., Ogundipe, O.O., Akande, E. A. and Isaiah, C. J. (2012). Production and quality evaluation of complementary food formulated from fermented sorghum, walnut and ginger. Journal of Applied Bioscience. 54 (3):3901-3910.

Adebayo-Oyetoro, D. A., Olatidoye, O.P., Ogundipe, O.O., Akande, E. A. and Isaiah, C.J. (2012). Production and quality evaluation of complementary food formulated from fermented sorghum, walnut and ginger. Journal of Applied Bioscience. 54(3):3901-3910.

Agunbiade, O., Shadraeh, O., Ojezele, O. J. and Omole, J. (2013). Improved weaning/breakfast diets formulated from Bambara and groundnut fortified maize, sorghum mix. Annals of Food science and Technology, 14: 54-58.

Akingbala, J.O. (1981). A laboratory procedure for the preparation of Ogi, A Nigerian fermented food". Journal of Food Science 46 (5): 1523-1526.

AOAC (2010). Association of Official and Analytical Chemist. Official method of Analysis Washington. DC.89 (13): $1549-1650$

AOAC (2012). Association of Official and Analytical Chemist. Official method of Analysis Washington. $\quad$ DC.44 (10): 149-157.

Awada Ikareem, A. M., Mustafa, A. I. and Eltinay, A. H. (2008). Protein Mineral Content and Amino Acid Profile of Sorghum Flour as Influenced by soya bean Protein concentrate supplementation, Pakistan Journal of Nutritional: 7(3):2008:475-479.

Bernard, T., Aduni, U. A., Bertrand, T. F., Noel, T., Eurydice, F. T. N. and Hilaire, M. W. (2016). Formulation and nutritional evaluation of instant weaning foods processed from maize (Zea mays), Pawpaw (Carica papaya), Red Beans (Phaseolus vulgaris) and Mackerel Fish Meal (Scomber scombrus). American Journal of Food Science and Technology. 4(5): 149-159 
Bintu, B. P., Hajjagana, L., Falmata, A.S., Modu, S. and Shettima, Y. (2015). Studies on the evaluation of the nutritional quality, chemical composition and rheological characteristics of a cereal fortified with legume as a weaning food blend. International Journal of Biotechnology and Food Science 3 (1): 1-9

Ekinci, R. and Kadaka, C. (2005). Determination of seven water soluble vitamins in Tarhana,atraditional Turkish cereal food, by high performance liquid chromatography, acta chromatogr.15, 289-297

Elemo, G. N., Elemo, J.N. and Okafor, C. (2011). Preparation and nutritional composition of a weaning food formulated from germinated sorghum (sorghum bicolor) and steamed cooked cowpea (Vigna unguiculara walp.).Agricultural Journal of Food Technology. 6:413-421.

Etukudo, M., Agbedana, O., Akang E, and Osifo, B. (1999). Biochemical Changes and Liver Tissue Pathology in Weanling Wistar Albino Rats with Protein-energy Malnutrition (PEM). African Journal of Medical Science. 28 (1-2): 43-7.

Falmata, A.S., Modu, S., Badau, H. D., Babagana, M. and Bintu, B.P. (2014). Formulation and evaluation of complementary weaning food prepared from single and combined sprouted/fermented local red sorghum $(S$. bicolor) variety blended with cowpea (Vigina unguiculata) and groundnut (Arachid hypogea). International Journal of Biotechnology and Food Science. (8): 149-155

FAO/WHO. (2017). Protein Advisory Group (PAG) of the United Nations. Food and Agricultural Organizati Rome. Guideline No 8. Protein-Rich Mixtures for Use as Weaning Food.New York:FAO/WHO/UNICEF.

Fasasi O.S. (2009). Proximate, antinutritional factors and functional properties of processed pearl millet (Pennisetum glaucum.) Journal of Food Technology. 73: 92-97.

Frazier W. C. and Westhoff, D. C. (1978). Food Microbiology. McGraw Hill publishing Co. Ltd. New York.

Gernah, D. I., Ariahu, C. C., Ingbain, E. K. and Sengev, A. I. (2011). Storage and Shelf Life Evaluation of Food Formulations from Malted and Fermented Maize (Zea mays L.) Fortified with Defatted Sesame (Sesamun indicum L.).Nigerian. Journal of Nutrition Science. 32(1):45 - 54.

Griffith L.D., Castell-Perez, M.E. and Griffith, M.E. (1998). Effects of blends and processing method on the nutritional quality of weaning foods made from selected cereals and legumes. Cereal Chemistry. 75(1): 105-112. https://www.fas.usda.gov/commodities/soybeans, accessed on 6/05/2021, 10:15pm

Huang Z. L. and Fraker P. J. (2003). Chronic consumption of a moderately low protein diet does not alter hematopoetic processes in young adult mice. Journal of Nutrition Science. 133: 1403-1408.

Ijarotimi, O.S. and Keshinro, O.O. (2013). Determination of nutrient composition and protein quality of potential complementary foods formulated from combination of fermented popcorn, Africa locust and bambara groundnut seed flour. Journal of Food and Nutrition Science. 63 (3): 155-166.

Islam, M. S., Chowdhury, A. B. M., Rahman, Z., Haque, M., Nahar, N. and Taher A. (2007). Serum Aspartate Aminotransferase (AST) and Alanine Aminotransferase (ALT) Levels in different grades of protein-energy malnutrition. Journals of Bangladesh Society Physiology.2: 17-19.

Kulkarni, R. R., Patki, P. S. and Jov, V. P. (1991). Treatment of osteoarthritis with a herbomineral formulation.A double-blinded, placebo controlled, cross-over study. Journals of Ethno Pharmacology; 33. 91-95.

Laminu, H. H., Modu, S. and Muhammad, A. A. (2014). Evaluation of the chemical composition, anti-nutrients and mineral element level of a composite meal from pearl millet, wheat, cowpea and groundnut. Sky Journal of Food Science. 3 (6): 061 - 070. 
Mbaeyi, I. E. and Onweluzo, J. C. (2010). Effect of sprouting and pre-gelatinization on the physic-chemical properties of sorghum-pigeon pea composite blend used for the production of breaking cereal. Journal of Tropical Agriculture, Food, Environment and Extension 9(1):8-17.

Mbata, T. I. M.J. Ikenebomen, M. J. and Akonkhai, I. (2007). Nutirional Status of Maize Fermented meal by Fortification with Bambara. African Journal of Food Agriculture and Nutrition Development. 7(2): 1-14.

Modu, S., Chamba, G, Falmata, A. S., Laminu, H. H., Babagana, M. and Hauwa, H. (2015). Studies on the effect of drying and varietal differences on chemical composition of some selected onion cultivars. Ecronicon Nutrition: 2(4): 376-385.

Modu, S., Falmata, A. S., Laminu, H. H. and Bintu, B. P. (2012). Production and evaluation of chemical composition, tannin, In vitro protein digestibility and microbiological studies of fermented local variety of sorghum, fortified with cowpea and groundnut. Bioscience research: $99-105$

Modu, S., Laminu, H. H. and Abba, S. F. (2010). Evaluation of the nutritional value of a composite meal prepared from pearl millet (Pennisetum typhoideum) and cowpea (Vigna unguiculata)" Journal of Applied Science. 3(1):164-168.

Nout, M. J. R. (1991). Weaning foods of tropical climates, proceedings of the regional IFS workshop on traditional africa on food quality and nutrition, (RIWTAFQNI '91) Dar-El-Salam, Tanzania, 23-31.

Obimba, K. C. (2006). Utilization of high quality weaning formulae as dietary therapies of protein-energy malnutrition. International Journals of Biochemistry and Biotechnology.1:230-238

Okaka, J. C. and Potter, N.N. (1977). Functional and storage properties of cowpea-wheat flour blends in bread making. Journal of Food Science. 42: 828-833

Oladeji, B. S. (2014). Physico-Chemical and nutritional evaluation of Co-processed fermented yellow maize Ogi (An Infant Diet) and carrot blends. Annals: Food Science and Technology 15.1: 82-91.

Onofiok, N. O. and Nnanyelugo D. O. (1998). Weaning foods in West African. Food and Nutrition Bulletin. The UN University.

Onweluzo, J.C. and Nwabugwu, C.C. (2009). Development and evaluation of weaning foods from pigeon pea and millet Pak. Journal of Nutrition. 8 (6):725-730).

Oyarekua, M.A. and Eleyinmi A.F. (2004). Comparative evaluation of the nutritional quality of corn, sorghum and millet 'ogi' prepared by modified traditional technique. Food Agricultural Environment. 2 (2), 94-99.

Shishira M. (2016). Malnutrition. Laboratory markers vs nutritional assessments. Gastrenterology report. $\quad \mathbf{4 ( 4 ) .}$ $272-280$

Tome, D. and Cecile, B. (2000). Dietary protein and nitrogen utilization. Journal of Nutrition. 130: 1868-1873.

USAID (2018). Commodities Reference Guide- Part II, Module I: Material Child Health andNutrition;www.A: INutrition facts. Htm.

USDA (2020). National nutrient database for seeds and legumes

USP (2017). United States pharmacopeia national formulary. A compendium for analytical method. Vol. 1pp 380-569

WHO/UNICEF (2018). Global Prevalence of Vitamin A Deficiency: Micronutrient Deficiency Information system. Working page 2 General: WHO 